BÁRBARA LYRIO URSINE

SAÚDE DAS PESSOAS COM DEFICIÊNCIA DO CAMPO NO ÂMBITO DA ATENÇÃO BÁSICA: PERCEPÇÕES DOS TRABALHADORES E REFLEXÕES SOBRE POLÍTICAS DE EQUIDADE PARA PESSOAS EM SITUAÇÃO DE DUPLA VULNERABILIDADE 


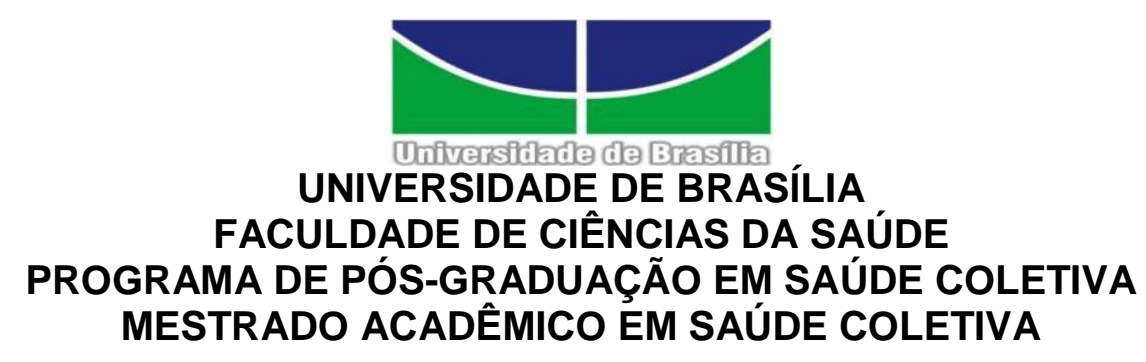

BÁRBARA LYRIO URSINE

SAÚDE DAS PESSOAS COM DEFICIÊNCIA DO CAMPO NO ÂMBITO DA ATENÇÃO BÁSICA: PERCEPÇÕES DOS TRABALHADORES E REFLEXÕES SOBRE POLÍTICAS DE EQUIDADE PARA PESSOAS EM SITUAÇÃO DE DUPLA VULNERABILIDADE Dissertação apresentada como requisito parcial para
obtenção do título de Mestre em Saúde Coletiva pelo
Programa de Pós-Graduação em Saúde Coletiva da
Universidade de Brasília.

Orientador: Prof. Pós Dr. Fernando Ferreira Carneiro Co-orientador: Prof. Dr. Éverton Luís Pereira

BRASÍLIA 


\title{
SAÚDE DAS PESSOAS COM DEFICIÊNCIA DO CAMPO NO ÂMBITO DA ATENÇÃO BÁSICA: PERCEPÇÕES DOS TRABALHADORES E REFLEXÕES SOBRE POLÍTICAS DE EQUIDADE PARA PESSOAS EM SITUAÇÃO DE DUPLA VULNERABILIDADE
}

\author{
Dissertação apresentada como requisito parcial para \\ obtenção do título de Mestre em Saúde Coletiva pelo \\ Programa de Pós-Graduação em Saúde Coletiva da \\ Universidade de Brasília. \\ Orientador: Prof. Pós Dr. Fernando Ferreira Carneiro \\ Co-orientador: Prof. Dr. Éverton Luís Pereira
}

Aprovado em 31 de agosto de 2016.

BANCA EXAMINADORA

Fernando Ferreira Carneiro

Departamento de Saúde Coletiva da Universidade de Brasília - UnB Presidente

\section{Ximena Pamela Díaz Bermúdez}

Departamento de Saúde Coletiva da Universidade de Brasília - UnB

Examinador interno

Lívia Barbosa Pereira

Departamento de Serviço Social da Universidade de Brasília - UnB

Examinador externo

Vera Lúcia Ferreira Mendes

Pontifícia Universidade Católica de São Paulo

Suplente 


\section{AGRADECIMENTOS}

Ao Professor Fernando Ferreira Carneiro e aos pesquisadores/colaboradores do Observatório de saúde das populações do campo, da floresta e das águas - Teia de Saberes e Práticas (OBTEIA)/Universidade de Brasília(UnB) pela oportunidade de colaborar e aprender na "Pesquisa Avaliativa da Implantação da Política Nacional de Saúde Integral para as Populações do Campo, da Floresta e das Águas (PNSIPCFA) em distintos cenários do Brasil".

Ao Professor Éverton Luís Pereira, pela orientação dedicada e generosa, que possibilitou o aprimoramento no desenvolvimento da pesquisa e construção desta dissertação, assim como no meu amadurecimento acadêmico, profissional e pessoal.

Aos participantes da fase exploratória da pesquisa, pela receptividade no território e por apresentar a realidade local, desdobrando no meu retorno na fase sistemática.

Aos Gestores da Secretaria Municipal de Saúde de Grão Mogol e trabalhadores da Unidade Básica de Saúde, por autorizar, confiar e acreditar na pesquisa de campo, contribuindo para a produção de conhecimento.

À Coordenadora Geral de Saúde da Pessoa com Deficiência/DAPES/SAS/MS e Professora Vera Lúcia Ferreira Mendes, pela oportunidade de trabalhar na implantação da Rede de Cuidados à Pessoa com Deficiência/Viver sem Limite e convocar ao compromisso ético-político dessa ação, que me fortaleceu para concluir esta dissertação.

À equipe de trabalho da Coordenação Geral de Saúde da Pessoa com Deficiência/DAPES/SAS/MS, pelo intenso aprendizado no cotidiano do trabalho e compreensão dos meus momentos de ausência que foram imprescindíveis para gestar esta dissertação.

Aos amigos gestores e aos pesquisadores, pelas valiosas contribuições e sugestões de ajustes na produção da dissertação. Dentre eles, destaco aqueles que me fortaleceram nos momentos mais necessários: Luísa da Matta Machado Fernandes, Vinícius Oliveira De Moura Pereira, Luciana d'Ávila e Nubia Vianna. 
Aos meus pais, Fernanda e Eduardo, pelo incentivo na realização desse sonho e apoio incondicional. Essa conquista é nossa.

Aos defensores do SUS, pela inspiração na luta por equidade, integralidade, universalidade, gratuidade e de qualidade da saúde.

Agradeço, por fim, a Deus pelos aprendizados, por iluminar meus caminhos e me dar forças para seguir adiante. 
"A utopia está lá no horizonte. Me aproximo dois passos, ela se afasta dois passos. Caminho dez passos e o horizonte corre dez passos. Por mais que eu caminhe, jamais alcançarei.

Para que serve a utopia? Serve para isso: para que eu não deixe de caminhar". Eduardo Galeano 


\section{RESUMO}

A Atenção Básica deve ser contato preferencial dos usuários com vistas a garantir o direito à saúde da pessoa com deficiência do campo que vivem uma condição de dupla vulnerabilidade. A inserção da interseccionalidade nas políticas de saúde pode revelar as desigualdades múltiplas. O objetivo desta pesquisa é investigar sobre a saúde das pessoas com deficiência do campo em uma Unidade Básica de Saúde, no município de Grão Mogol, Minas Gerais. Trata-se de uma pesquisa qualitativa que se fundamentou na investigação emancipatória da deficiência e foi desenvolvida em duas etapas: empírica e teórica. A investigação empírica, na modalidade compreensiva, de cunho etnometodológico na fase sistemática, sendo realizada observação participante e debates por meio da roda, com registro em diário de campo, e entrevistas semiestruturadas com os trabalhadores da Estratégia Saúde da Família. Na análise, combinaram-se os dados coletados para Triangulação. A pesquisa teórica derivou da empírica para aprofundar reflexões sobre políticas de saúde a partir dos princípios da equidade e integralidade, debatendo os conceitos de ruralidades, deficiência e interseccionalidade. Constatou-se na pesquisa de campo que as políticas desenvolvimentistas e inserção das políticas públicas estão transformando a vida da população do campo. A deficiência está ancorada no modelo biomédico e a dimensão da caridade se ressalta nas ações em saúde desenvolvidas pela Unidade Básica de Saúde investigada. A fim de enfrentar as barreiras de acesso à saúde, o desenho da Rede de Cuidados à Pessoa com Deficiência deve ser repactuado. Constatouse na investigação teórica que as concepções de ruralidade e do modelo social da deficiência, que emergiram do debate crítico ao modelo hegemônico, fundamentaram as políticas de saúde para população do campo e para pessoas com deficiência. Verificou-se também que a dupla vulnerabilidade da população do campo com deficiência não é discutida na literatura nacional e tem sido pouco abordada expressamente em documentos oficiais dessas políticas. O espaço na agenda política foi conquistado através da Rede de Cuidados à Pessoa com Deficiência e da Política Nacional de Saúde Integral para as Populações do Campo, da Floresta e das Águas, valorizando a Atenção Básica como contato preferencial na rede de atenção à saúde. A inserção da interseccionalidade nas políticas de equidade pode contribuir para repensá-las na perspectiva das desigualdades múltiplas, revelando a realidade social e propiciando a ampliação do acesso e qualificação do atendimento à população do campo com deficiência.

Palavras-chave: Pessoas com deficiência; Saúde da população rural; Atenção Primária à Saúde; Equidade em Saúde; Integralidade em Saúde; Acesso aos Serviços de Saúde. 


\begin{abstract}
The Primary Care should be preferred contact of users with a view to ensuring the right to health of the person with disability field who live a double condition of vulnerability. The insertion of intersectionality in health policies can reveal the multiple inequalities. The objective of this research is to investigate on the health of people with disabilities field in a Basic Health Unit in the city of Grand Mogol, Minas Gerais. This is a qualitative research that was based on the emancipatory research deficiency and was developed in two stages: theoretical and empirical. Empirical research, comprehensive mode of ethnomethodological nature of the systematic phase, being conducted participant observation and discussions through the wheel with journaling field, and semi-structured interviews with workers of the Family Health Strategy. The analysis combined the data collected to Triangulation. The theoretical research derived from empirical to deepen reflections on health policies based on the principles of fairness and integrity, discussing the concepts of ruralities, disability and intersectionality. It was found in field research that development policies and integration of public policies are transforming the lives of rural people. Disability is anchored in the biomedical model and the size of the charity is emphasized in health actions developed by the Basic Health Unit investigated. In order to address the health access barriers, the design of People with Disabilities in Care Network should be renegotiated. It was found in theoretical research that the concepts of rurality and the social model of disability, which emerged from the critical debate to the hegemonic model, substantiate health policies for the rural population and people with disabilities. It was also found that the double vulnerability of rural people with disabilities is not discussed in the national literature and has expressly been rarely addressed in official documents such policies. The space on the political agenda has been achieved through the People with Disabilities in Care Network and the National Comprehensive Health Policy for the Field Populations, Forest and Water, enhancing primary care as the preferred contact on the network of health care. The insertion of intersectionality in equity policies can contribute to rethink them in view of the multiple inequalities, revealing the social reality and providing increased access and qualification of care to the rural population with disabilities.
\end{abstract}

Keywords: Disabled persons; Rural health; Primary Health Care; Health equity; integrality in health; Health services accessibility. 


\section{LISTA DE ILUSTRAÇÕES}

Figura 1 - Distrito Porta do Mundo, Grão Mogol, norte de Minas Gerais.

Página

17

Quadro 1 - Concepções teóricas do rural na literatura

Quadro 2 - Políticas de saúde para população do campo

Quadro 3 - Concepções teóricas de deficiência na literatura 48

Quadro 4 - Políticas de saúde para pessoa com deficiência 50 


\section{LISTA DE ABREVIATURAS E SIGLAS}

$\begin{array}{ll}\text { ACS } & \text { Agentes Comunitários de Saúde } \\ \text { CAPS } & \text { Centro de Atenção Psicossocial } \\ \text { CEO } & \text { Centro de Especialidades Odontológicas } \\ \text { CIF } & \text { Classificação Internacional de Funcionalidade, Incapacidade e Saúde } \\ \text { ESF } & \text { Estratégia Saúde da Família } \\ \text { IBGE } & \text { Instituto Brasileiro de Geografia e Estatística } \\ \text { ICIDH } & \text { Classificação Internacional de Lesão, Deficiência e Handicap } \\ \text { IDHM } & \text { Índice de Desenvolvimento Humano Municipal } \\ \text { IDSUS } & \text { Índice de Desempenho do Sistema Único de Saúde } \\ \text { MAB } & \text { Movimento dos Atingidos por Barragens } \\ \text { MG } & \text { Minas Gerais } \\ \text { NASF } & \text { Núcleo de Apoio à Saúde da Família } \\ \text { OBTEIA/UnB } & \text { Observatório de saúde das populações do campo, da floresta e das } \\ & \text { águas - Teia de Saberes e Práticas/Universidade de Brasília } \\ \text { OMS } & \text { Organizacaão Mundial de Saúde } \\ \text { ONU } & \text { Organizacão das Nações Unidas } \\ \text { PNAB } & \text { Política Nacional de Atenção Básica } \\ \text { PNSIPCFA } & \text { Política Nacional de Saúde Integral para as Populações do Campo, da } \\ & \text { Floresta e das Águas } \\ \text { PSE } & \text { Programa Saúde na Escola } \\ \text { RCPCD } & \text { Rede de Cuidados à Pessoa com Deficiência } \\ \text { SGEP/MS } & \text { Secretaria de Gestão Estratégica e Participativa (SGEP)/Ministério da } \\ & \text { Saúde(MS) } \\ \text { SUS } & \text { Sistema Único de Saúde } \\ \text { TCLE } & \text { Termo de Consentimento Livre e Esclarecido } \\ \text { UBS } & \text { Unidade Básica de Saúde }\end{array}$




\section{SUMÁRIO}

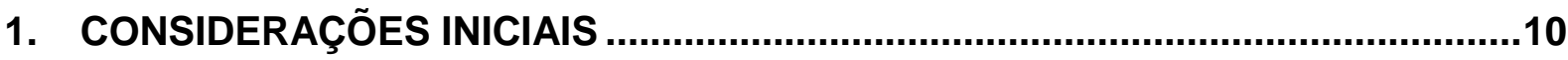

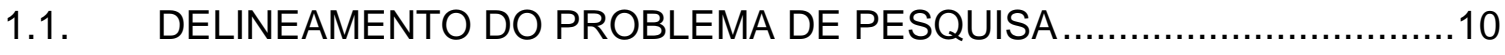

1.2. APRESENTAÇÃO DO TERRITÓRIO DA PESQUISA EMPÍRICA .............13

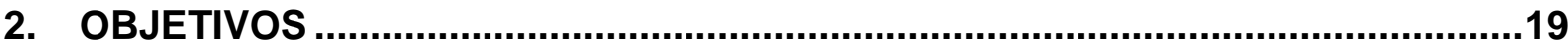

3. MÉTODOS.......................................................................................................20

3.1. PRODUÇÃO DE CONHECIMENTO NA ABORDAGEM QUALITATIVA ..............20

3.2. PRODUÇÃO DO CONHECIMENTO EMANCIPATÓRIO NAS PESQUISAS

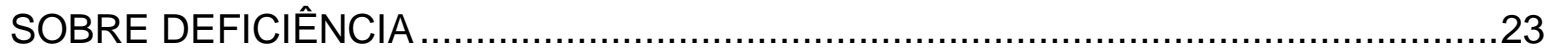

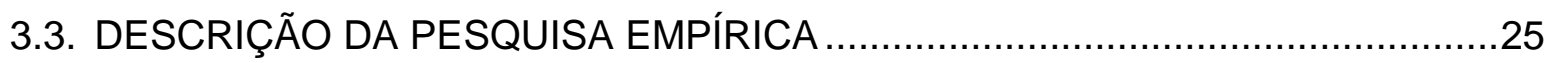

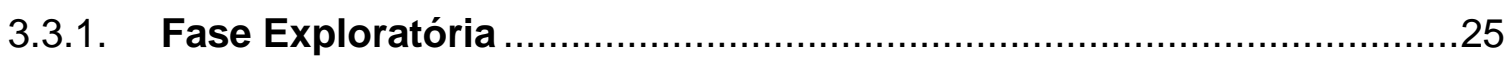

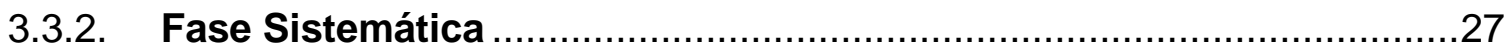

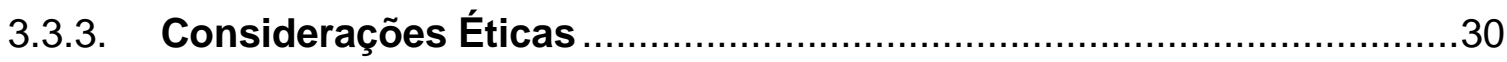

3.3.4. Informações Sobre Os Paricipantes Entrevistados ...........................31

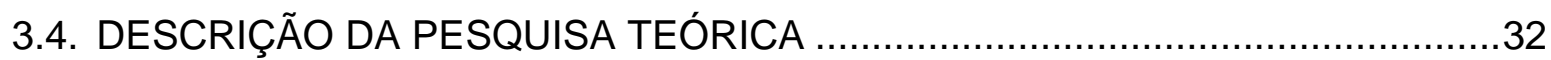

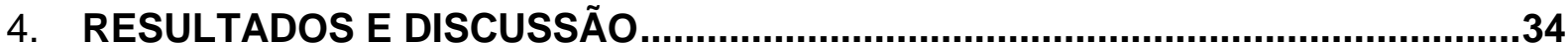

4.1. ARTIGO TEÓRICO - EQUIDADE E INTEGRALIDADE NA ATENÇÃO BÁSICA: REFLEXÕES SOBRE POLÍTICA DE SAÚDE PARA POPULAÇÃO DO CAMPO COM DEFICIÊNCIA

4.2. ARTIGO EMPÍRICO - SAÚDE DA PESSOA COM DEFICIÊNCIA DO CAMPO: O QUE DIZEM OS TRABALHADORES DA ATENÇÃO BÁSICA?

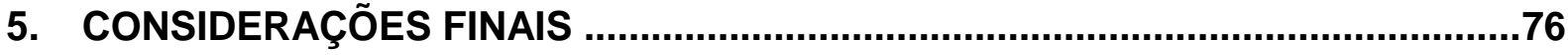

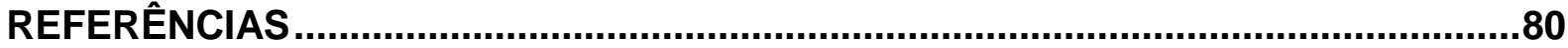

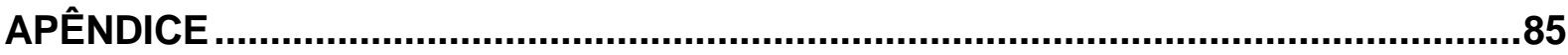

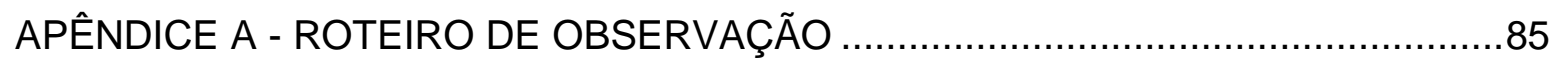

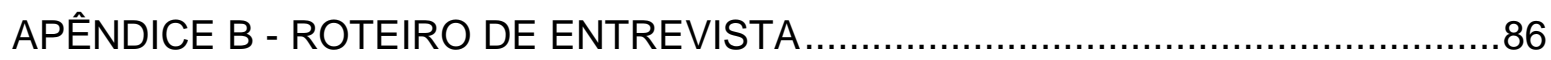

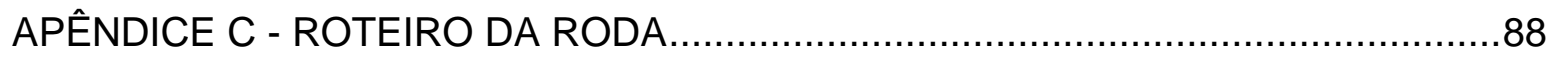

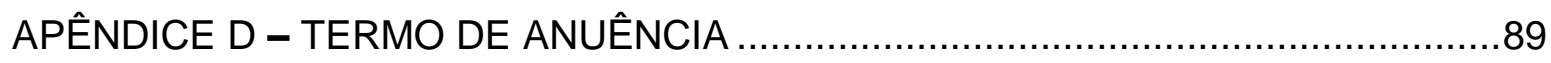

APÊNDICE E - TERMO DE CONSENTIMENTO LIVRE E ESCLARECIDO .............90

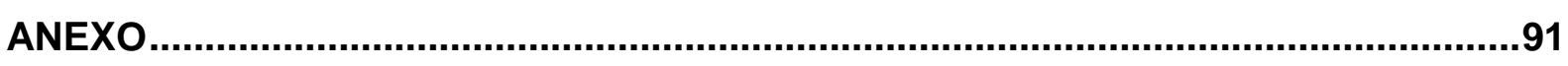

ANEXO A - PARECER CONSUBSTANCIADO DO CEP ...................................91

ANEXO B - COMPROVANTE E SUBMISSÃO À REVISTA INTERFACE ................92 


\section{CONSIDERAÇÕES INICIAIS}

Este capítulo foi estruturado em duas seções. A primeira apresenta o delineamento do problema de pesquisa da presente dissertação e a segunda seção versa sobre o território da pesquisa empírica.

\subsection{DELINEAMENTO DO PROBLEMA DE PESQUISA}

A Atenção Básica é central na organização das políticas de saúde com vistas à consolidação dos princípios do Sistema Único de Saúde (SUS), destacando que a Estratégia Saúde da Família (ESF) como prioritária para reorganização do modelo de atenção à saúde (BRASIL, 2012a). Na Política Nacional da Atenção Básica PNAB, a Atenção Básica é definida como:

\footnotetext{
um conjunto de ações de saúde, no âmbito individual e coletivo, que abrange a promoção e a proteção da saúde, a prevenção de agravos, o diagnóstico, o tratamento, a reabilitação, redução de danos e a manutenção da saúde com o objetivo de desenvolver uma atenção integral que impacte na situação de saúde, na autonomia das pessoas e nos determinantes e condicionantes de saúde das coletividades (BRASIL, 2012a, p.19).
}

A Atenção Básica, portanto, é apontada no âmbito do SUS como principal porta de entrada, sendo contato preferencial dos usuários, e ordenadora das redes de atenção à saúde a fim de garantir o direito à saúde (BRASIL, 2012a). Compete à Atenção Básica desenvolver ações estratégicas para a ampliação do acesso e da qualificação da atenção à saúde no âmbito da Rede de Cuidados à Pessoa com Deficiência - RCPCD (BRASIL, 2012b). Paralelamente, a importância da Atenção Básica é ressaltada a fim de garantir acesso à saúde com equidade na Política Nacional de Saúde Integral para as Populações do Campo, da Floresta e das Águas - PNSIPCFA (BRASIL, 2013). É necessário destacar que essas políticas específicas de saúde foram recentemente instituídas e estão sendo implantadas no SUS, reconhecendo a importância da Atenção Básica para promover melhorias na saúde das pessoas com deficiência e da população do campo. 
A priorização das atividades desenvolvidas pela Atenção Básica deve considerar o critério de vulnerabilidade (BRASIL, 2012a), sendo esta compreendida como um conjunto de fragilidades individuais e precariedades sociais que atingem um sujeito cujas condições de vida e saúde são influenciadas ou determinadas por aspectos sócio-históricos (AYRES, CALAZANS, SALETTI FILHO e FRANÇAJÚNIOR, 2006). Esta dissertação aborda as condições de dupla vulnerabilidade das pessoas com deficiência que vivem no campo na vida social. A população do campo com deficiência sofre discriminação qualitativamente diversa daquela vivida pela população da zona urbana com deficiência ou pela população do campo sem deficiência, porque cada pessoa ou grupo populacional experimenta distintas opressões e privilégios.

As pessoas com deficiência apresentam piores condições de saúde e de vida quando comparadas às pessoas sem deficiência, em parte, devido ao fato de enfrentarem barreiras no acesso aos bens e serviços fundamentais (OMS, 2012). A deficiência está relacionada a desvantagens, afetando desproporcionalmente populações vulneráveis. Pessoas com deficiência, nesta dissertação, são definidas como "aquelas que têm impedimento de natureza física, intelectual ou sensorial, os quais, em interação com diversas barreiras, podem obstruir sua participação plena e efetiva na sociedade com as demais pessoas". Essa denominação foi consagrada na Convenção sobre os Direitos das Pessoas com Deficiência, aprovada pela Organização das Nações Unidas (ONU) e promulgada com equivalência de emenda constitucional no Brasil (BRASIL, 2009), dialogando com o modelo biomédico e social de deficiência (DINIZ, 2007; OLIVER, 1992). Ambos os modelos explicativos serão discutidos no Capítulo 4 desta dissertação.

A população do campo no Brasil apresenta restrições ao acesso aos bens e serviços indispensáveis à vida, bem como se constata piores condições de saúde e de vida se comparada com quem vive na zona urbana (BRASIL, 2013). As denominações "Campo" e "Rural" são consideradas sinônimas nesta dissertação num entendimento mais amplo, o qual corrobora com a concepção de ruralidade Essa perspectiva extrapola a noção de se apresentar apenas um espaço de produção, revelando a diversidade do rural e reconhecendo-o como lugar de vida e expressão cultural da população que lá vive (BEZERRA, BACELAR, MIRANDA e 
SILVA, 2013). O debate sobre ruralidades será aprofundado no Capítulo 4 do presente estudo.

A escassa e limitada literatura nacional e internacional sugere que pessoas com deficiências do campo têm a condição de saúde mais comprometida do que a população do campo sem deficiência (LISHNER, RICHARDSON, LEVINE e PATRICK, 1996). É necessário destacar que tanto as pessoas com deficiência, quanto aquelas que vivem no campo, relatam muitos dos mesmos tipos de dificuldades de acesso (IEZZONI, KILLEEN e O'DAY, 2006). As barreiras, muitas vezes, parecem ser mais acentuadas para pessoas com impedimento que vivem as seguintes adversidades: pouco conhecimento do médico sobre deficiência, dificuldade na identificação dos problemas de saúde pela Atenção Básica e Especializada, problema local de transporte, inadequação do acesso físico e inacessibilidade das informações. Essas pessoas parecem viver em maior desvantagem quanto às condições de saúde, uma vez que a deficiência e a vida no campo estão associadas a menor número de oportunidades de educação e emprego, à falta de transporte público acessível e a dificuldades comunicacionais e no acesso a serviços de saúde (FRANCISCO e RAVESLOOT, 2012).

A fim de transcender os limites da análise de apenas uma das vulnerabilidades e de revelar invisibilidades perpetuadoras de injustiças, a intersecção entre esses dois eixos de desigualdade é fundamentada na interseccionalidade ${ }^{1}$ nesta dissertação. Trata-se de um conceito analítico potente para interpretar a realidade e atuar adequadamente sobre ela, visando a sua transformação a partir da compreensão do entrecruzamento dos eixos de subordinação que produzem desigualdades (MELLO e GONÇALVES, 2010). Apesar da literatura sobre políticas de equidade discutir sobre a inserção da interseccionalidade a fim de contribuir para repensá-las como desigualdades múltiplas (ALONSO, 2010), essa perspectiva tem sido pouco abordada na literatura referente às políticas de saúde para população do campo e para pessoa com deficiência.

\footnotetext{
${ }^{1}$ Kimberl Crenshaw introduziu o debate conceitual sobre a discriminação interseccional ao se referir sobre os direitos humanos das mulheres negras (ALONSO, 2010). A interseccionalidade busca capturar as consequências estruturais e dinâmicas da interação entre dois ou mais eixos da subordinação determinadas pelo sexismo, racismo e patriarcalismo, evitando distorções e invisibilidades no trato de casos de discriminação e possibilitando compreender o fenômeno discriminatório de forma mais abrangente e complexa.
} 
É nesse contexto que se insere a presente pesquisa. As questões que orientam esta dissertação são: Como está a saúde da pessoa com deficiência do campo no âmbito da Atenção Básica? Quais são as percepções dos trabalhadores da ESF sobre a saúde da pessoa com deficiência do campo? As políticas de saúde compreendem a dupla vulnerabilidade da pessoa com deficiência do campo? Os pressupostos deste estudo são: 1) a Atenção Básica é central na garantia do direito à saúde da pessoa com deficiência do campo; 2) a Pessoa com deficiência do campo vive em uma situação de dupla vulnerabilidade; 3) a inserção da interseccionalidade nas políticas de saúde pode revelar as desigualdades múltiplas. O Distrito "Porta do Mundo" foi o local no qual a pesquisa empírica ocorreu para que os trabalhadores da ESF revelassem suas percepções sobre a saúde da pessoa com deficiência do campo. O território da investigação de campo será apresentado na próxima seção.

\subsection{APRESENTAÇÃO DO TERRITÓRIO DA PESQUISA EMPÍRICA}

O Distrito "Porta do Mundo" - nome fictício ${ }^{2}$ - está localizado no município de Grão Mogol, norte de Minas Gerais (MG), distando $51 \mathrm{~km}$ da sede municipal por acesso de terra e $101 \mathrm{~km}$ por acesso com pavimentação asfáltica. Grão Mogol possui uma população de 15.024 habitantes, com área territorial de $3.885,294 \mathrm{~km}^{2} \mathrm{e}$ densidade populacional de $3,87 \mathrm{hab} / \mathrm{km}^{2}$ (IGBE, 2010). A população masculina do município de Grão Mogol corresponde a $51,43 \%$ e a feminina $48,57 \%$. Os dados do Censo de 1991, 2000 e 2010 revelam o aumento da taxa de envelhecimento entre os residentes, bem como alteração da pirâmide etária (PNUD, 2013). A população de Grão Mogol cresceu menos do que a população brasileira entre 2000 e 2010, enquanto a taxa de urbanização aumentou discretamente para $35,88 \%$.

\footnotetext{
${ }^{2}$ Optou-se por utilizar o nome fictício para preservar a identidade dos participantes da pesquisa que poderiam ser identificados pela UBS que trabalham, visto que no referido Distrito há apenas este estabelecimento de saúde.
} 
Trata-se de uma região com características climáticas muito variáveis, abrangendo climas sub-úmido a semiárido, e rica biodiversidade do Cerrado, fazendo transição com a Caatinga e a Mata Atlântica (IGBE, 2010). O município compõe o polígono da seca em função da estiagem provocada pela instabilidade do clima, mobilizando historicamente a intervenção do Estado.

Em 2010, o Índice de Desenvolvimento Humano Municipal (IDHM) ${ }^{3}$ de Grão Mogol foi de 0,604 o qual se situa na faixa mediana, apresentando-se na $768^{\text {a }}$ posição em relação aos 853 municípios de MG (PNUD, 2013). Vale destacar que o IDHM em 1991 era 0,323 e seu aumento se justifica em função da contribuição, em ordem decrescente, das seguintes dimensões: renda, longevidade, e educação.

$18,7 \%$ da população de Grão Mogol são analfabetas, sendo que dentre os residentes em área rural é 22,4\% (IBGE, 2010). Observa-se que esse indicador nas áreas rurais desse município foi sempre pior que nas áreas urbanas ao se comparar os dados dos Censos de 1991, 2000 e 2010, embora a diferença percentual tenha apresentado redução ao longo das últimas décadas (PNUD, 2013). Ainda quanto ao analfabetismo, observa-se sua redução ao longo das últimas três décadas, no entanto ainda é preocupante no município de Grão Mogol, especialmente nas faixas etárias acima de 40 anos de idade (IBGE, 2010).

95,59\% da população de Grão Mogol vivem em domicílios com energia elétrica, $57,37 \%$ dos residentes têm acesso ao abastecimento de água em seu domicílio, 5,31\% das pessoas residem em domicílios com o abastecimento de água e o esgotamento sanitário inadequados, $67,73 \%$ da população têm banheiro e água encanada no domicílio (IBGE, 2010).

\footnotetext{
${ }^{3} \mathrm{O}$ IDHM é uma unidade de desenvolvimento humano do município o qual é calculado a partir de três dimensões no município: Educação, Longevidade e Renda (PNUD, 2013).
} 
A renda per capita média de Grão Mogol cresceu $67,81 \%$ entre os anos de 1991 a 2010, passando de $R \$ 175,12$ para $R \$ 293,87$ (PNUD, 2013). Nesse município, a proporção de pessoas pobre ${ }^{4}$ e extremamente pobres ${ }^{5}$ da população diminui ao longo dos anos, especialmente entre os anos de 2000 e 2010. A diminuição da desigualdade de renda entre os anos de 1991 a 2010 foi constatada pela oscilação no Índice de Gini'. Observou-se, em Grão Mogol, que valor do rendimento nominal médio mensal daquelas pessoas que residem no campo $(\$ 1.038,84)$ é menor quando comparado com aqueles que vivem na cidade $(\mathrm{R} \$ 1.412,47)$.

A mortalidade infantil em Grão Mogol reduziu para 19,6/mil nascidos vivos e a esperança de vida ao nascer aumentou para 72,4 anos, no entanto ainda continua aquém do indicador estadual (IBGE, 2010). No ano de 2014, foram registradas 927 internações nas quais a pessoa informou esse município como local de residência, sendo as principais causas: 204 doenças do aparelho respiratório, 149 doenças do aparelho circulatório, 111 transtornos mentais e comportamentais (BRASIL, 2015b).

Grão Mogol obteve 6,42 no Índice de Desempenho do Sistema Único de Saúde (IDSUS) ${ }^{7}$ que avalia o acesso e a efetividade do sistema de saúde nos três níveis de atenção à saúde: Atenção Básica, Atenção Ambulatorial e Hospitalar de Média e Alta Complexidade (BRASIL, 2015a). Vale destacar que, em geral, os indicadores da Atenção Básica são muito melhores do que o da atenção especializada na média e alta complexidade.

\footnotetext{
${ }^{4}$ As pessoas pobres têm renda domiciliar per capita abaixo de $R \$ 140,00$, considerando-se os preços de agosto de 2010.

5 As pessoas extremamente pobres têm renda domiciliar per capita abaixo de $R \$ 70,00$, considerando-se os preços de agosto de 2010.

${ }^{6} \mathrm{O}$ Índice de Gini é o indicador usado para medir o grau de concentração de renda.

${ }^{7}$ O IDSUS é um indicador composto que faz uma aferição contextualizada do desempenho do SUS, avaliando o acesso e a efetividade do Sistema de saúde brasileiro, variando de 0 a 10.
} 
A cobertura da ESF no município é $96,67 \%$, sendo que as ações em saúde são desenvolvidas por seis equipes distribuídas em cinco estabelecimentos de saúde (BRASIL, 2015a). Há também dois Postos de Saúde para atendimento à demanda espontânea na zona rural, 20\% de adesão ao Programa Saúde na Escola (PSE) e uma equipe de Núcleo de Apoio à Saúde da Família (NASF) composta por Fisioterapeuta, Pediatra, Educador Físico, Nutricionista e Assistente Social. Foram implantados em Grão Mogol os seguintes estabelecimentos de saúde no âmbito da atenção especializada: Centro de Especialidades Odontológicas (CEO), Centro de Atenção Psicossocial (CAPS), Centro de Saúde e Hospital Geral.

O povoado do Distrito "Porta do Mundo" está localizado às margens da BR251 e concentra os comércios, os serviços e edificações de públicas (Figura 1). Quanto à zona rural, situa-se distante do povoado, em média, $15 \mathrm{~km}$. A população cadastrada pela UBS do Distrito é estimada em 2.000 habilitantes. Essa UBS, único estabelecimento de saúde existente na localidade, dispõe de uma equipe da ESF formada por um Médico, um Enfermeiro, um Técnico de Enfermagem, sete Agentes Comunitários de Saúde (ACS) - com equipe de Saúde Bucal - formada por um Dentista e um Técnico de saúde bucal. A UBS também conta com dois trabalhadores ligados aos Serviços Gerais, dois Recepcionistas, três Técnicos de Enfermagem e um trabalhador na Farmácia. 


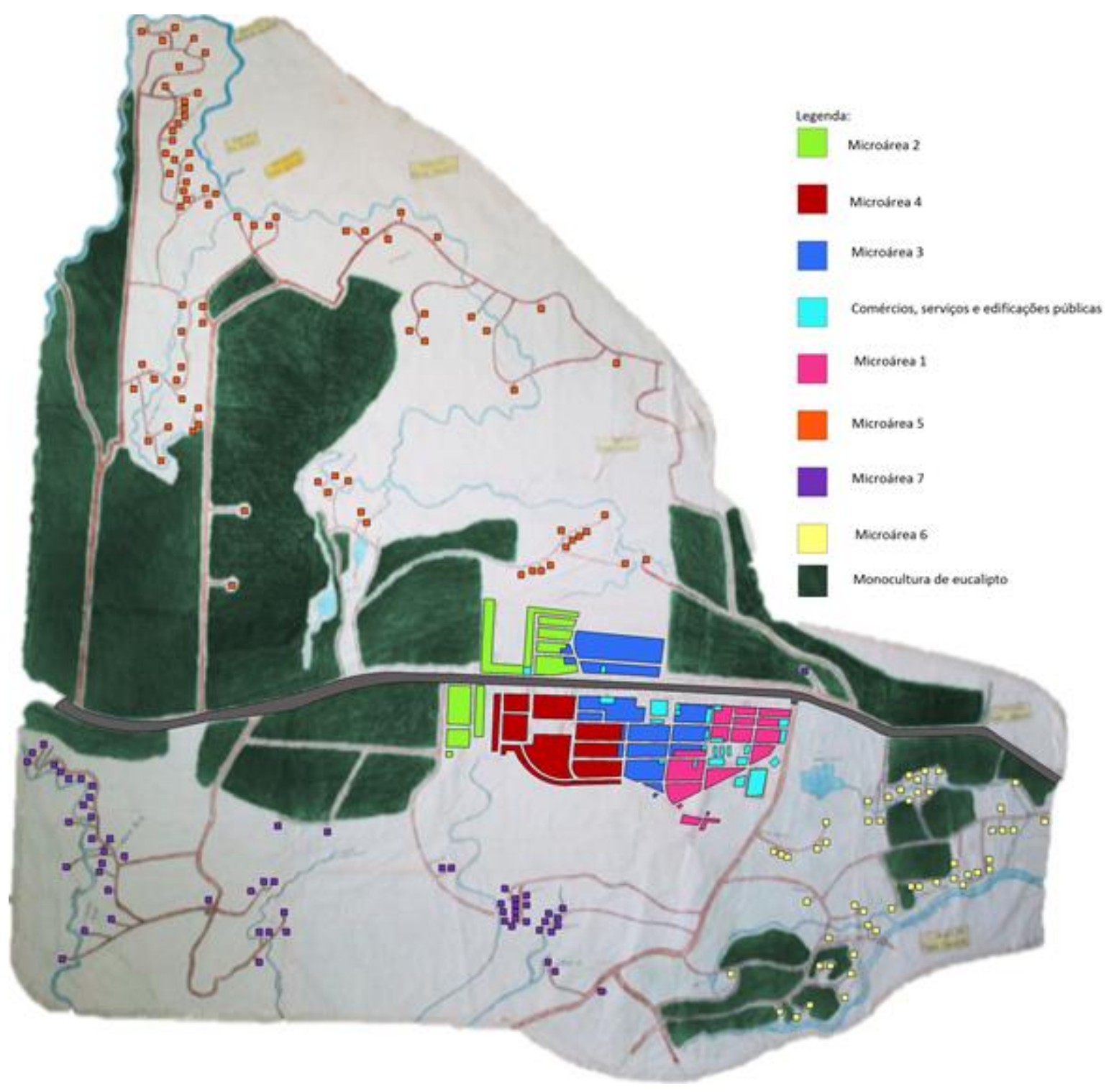

Figura 1 - Distrito Porta do Mundo, Grão Mogol, norte de Minas Gerais.

Fonte: Unidade Básica de Saúde do Distrito "Porta do Mundo", Grão Mogol, MG.

As inúmeras comunidades rurais da "Porta do Mundo" se reproduzem socialmente ao estabelecer relações de reciprocidade e solidariedade organizadas pelo parentesco e compadrio (FONSECA, 2014). Há pelo menos seis gerações que também se reproduzem economicamente e estão vinculadas fortemente ao ecossistema local que satisfaz as necessidades da família e da comunidade. O processo de êxodo local e o relativo isolamento, em relação à expansão capitalista regional, contribuíram para a manutenção do modo de vida dos camponeses locais que se reproduziam nos Gerais um modo de vida peculiar, baseando-se na 
agricultura de subsistência e no uso comum das chapadas para extrativismo e criação de gado (MATA MACHADO, 1991). As políticas de desenvolvimento implantadas no norte de Minas, ainda assim, provocaram a mercantilização da terra e o assalariamento das relações de trabalho, transformando o modo de vida camponês.

As Normas para redação de dissertações do Programa de Pós-Graduação em Saúde da Universidade de Brasília foram seguidas no formato da apresentação desta dissertação. Logo, seus resultados foram apresentados na forma de dois artigos, sendo que um destes artigos concentrou apresentou os resultados da pesquisa teórica e foi intitulado "Equidade e integralidade na Atenção Básica: reflexões sobre política de saúde para população do campo com deficiência", propondo-se a discutir a relevância da Atenção Básica do ponto de vista interseccional para se repensar a saúde da população do campo com deficiência. $O$ segundo manuscrito construído foi intitulado "Saúde da pessoa com deficiência do campo: o que dizem os trabalhadores da Atenção Básica?", baseando-se na pesquisa empírica que investigou a saúde da pessoa com deficiência na perspectiva dos trabalhadores da ESF. 


\section{OBJETIVOS}

Objetivo geral: Investigar as percepções sobre a saúde das pessoas com deficiência do campo na Unidade Básica de Saúde do Distrito "Porta do Mundo", Grão Mogol, Minas Gerais.

\section{Objetivos específicos:}

- Analisar as percepções sobre a saúde da pessoa com deficiência do campo a partir das narrativas dos trabalhadores da UBS "Porta do Mundo", Grão Mogol, Minas Gerais.

- $\quad$ Discutir a deficiência e as ruralidades a partir de princípios da Atenção Básica estruturantes nas políticas de saúde para população do campo e para pessoa com deficiência.

- Explicitar a interseccionalidade entre deficiência e ruralidade nas políticas de equidade em saúde para pessoas em situação de dupla vulnerabilidade. 


\section{MÉTODOS}

Este capítulo está estruturado em quatro seções. Diante da pertinência da abordagem qualitativa para compreender a complexidade e a dinâmica das relações sociais, a primeira seção discute a produção de conhecimento nessa perspectiva. Uma vez que os pressupostos epistemológicos da pesquisa se fundamentaram também na investigação emancipatória da pessoa com deficiência, a segunda seção traz esse debate. Vale informar que a investigação foi desenvolvida em duas etapas: empírica e teórica, sendo a pesquisa empírica descrita na terceira seção e pesquisa teórica abordada na quarta.

\subsection{PRODUÇÃO DE CONHECIMENTO NA ABORDAGEM QUALITATIVA}

A realidade científica é constituída pelos significados atribuídos a características objetivas quantitativamente mensuráveis e/ou qualitativamente observáveis. A natureza da pesquisa, nesse sentido, deve estar em consonância com o objeto de investigação (MINAYO, 2014), com os fundamentos teóricos e objetivos propostos. O bom método científico é aquele capaz de conduzir o pesquisador a alcançar as respostas para suas perguntas, propiciando liberdade para aprofundar na investigação de modo consistente. As abordagens quantitativa e qualitativa têm espaço específico e adequado, uma vez que os números e categorias empíricas são compreendidos como linguagens distintas no reconhecimento da realidade. Do ponto de vista metodológico, ambas são de natureza diferentes e, portanto, não há contraposição entre elas, podendo as investigações quantitativa e qualitativa ser complementares na compreensão da realidade. 
A pesquisa quantitativa, que está ancorada no paradigma positivista, tende a enfatizar o raciocínio dedutivo, as regras da lógica e os atributos mensuráveis da vida geralmente para descrever e interpretar os fenômenos biológicos, trazendo à luz dados, indicadores e tendências observáveis (MINAYO, 2014). A pesquisa qualitativa, no entanto, se preocupa com elementos da realidade que não podem ser quantificados, fundamenta-se no paradigma construtivista e está centrada na compreensão e explicação da dinâmica das relações sociais. Os aspectos dinâmicos da experiência humana são salientados para apreender o contexto daqueles que vivenciam o fenômeno estudado.

Vale destacar a existência do conflito entre os paradigmas positivistas e construtivistas no que tange à cientificidade ou não dos métodos de pesquisa (MINAYO, 2014). É comum a postura de atribuir status científico apenas ao que pode ser quantificado, sendo pouco tolerante aos estudos qualitativos. A cientificidade, no entanto, não pode ser reduzida a uma forma determinada de conhecer o mundo. A validade científica de cada abordagem, portanto, depende da pertinência, relevância e uso adequado dos instrumentos. Nenhuma das duas pesquisas é mais científica que a outra do ponto de vista epistemológico. Uma investigação com abordagem quantitativa não se torna objetiva nem melhor por si só. Da mesma forma, a pesquisa qualitativa não garante necessariamente a compreensão em profundidade do fenômeno investigado.

Os positivistas consideram que a pesquisa qualitativa é subjetiva e não científica, uma vez que não se ocupa com aspectos quantificáveis que possibilitariam evidenciar relações de causa e efeito. A investigação qualitativa, porém, ressalta a importância da objetivação, visto que na investigação científica tanto a complexidade do objeto de estudo, quanto à parcialidade e limitações na produção do conhecimento científico são reconhecidas (MINAYO, 2014). A pesquisa qualitativa também se propõe a rever criticamente as teorias sobre o tema, utilizar técnicas de coleta de dados adequadas e analisar o material de forma específica e contextualizada. 
A investigação qualitativa deve ser desenvolvida contextualizada à realidade local, investindo-se em conhecer a organização social, cultural e econômica de determinado momento histórico (MINAYO, 2014). Torna-se preciso, para isso, que o pesquisador se disponha a se aproximar e olhar por vários ângulos para compreender a realidade social, levando em consideração a participação e as percepções dos sujeitos. A subjetividade e o simbolismo são condições essenciais nessa abordagem para revelar as intenções e os motivos que dão sentido às ações e relações. A pesquisa qualitativa, portanto, utiliza métodos que incorporam 0 significado e a intencionalidade como inerentes aos atos e às estruturas sociais.

A abordagem qualitativa tenta reproduzir a realidade fundamentada nas relações e representações dos atores sociais (MINAYO, 2014). Vale esclarecer que eles são apontados como ativos na produção do conhecimento, sendo o pesquisador compreendido como produtor e produto. $\mathrm{O}$ envolvimento entre participantes e pesquisador não é considerado uma ameaça, pelo contrário, é necessária como condição de aprofundamento da relação intersubjetiva. As relações de poder inerentes do processo social e, consequentemente, dos encontros de pesquisa, assim como a rede de implicações e o engajamento político dos atores sociais são reconhecidos, revelando seus interesses e visões de mundo determinados aspectos sócio- históricos.

Dessa forma, a investigação qualitativa foi escolhida nessa pesquisa pela sua adequação para trabalhar com os significados, motivos, crenças, valores e atitudes, o que corresponde a um espaço mais profundo das relações, processos e fenômenos que não podem ser reduzidos à operacionalização de variáveis. Os pressupostos epistemológicos da pesquisa qualitativa aqui empreendida, portanto, fundamentaram o processo de produção do conhecimento ao se questionar a objetividade da realidade, a neutralidade do pesquisador e a dicotomia na relação entre sujeito e objeto.

Os demais pressupostos epistemológicos desta pesquisa são abordados na próxima seção que versa sobre a investigação emancipatória da deficiência no contexto das propostas de ciência moderna. 


\subsection{PRODUÇÃO DO CONHECIMENTO EMANCIPATÓRIO NAS PESQUISAS SOBRE DEFICIÊNCIA}

As pesquisas sobre deficiência ancoradas no paradigma científico positivista têm sido ineficazes (OLIVER, 1992). O pesquisador nesses estudos assume uma posição privilegiada de poder e de neutralidade na produção científica, contribuindo para reproduzir a marginalização e opressão das pessoas com deficiência no ato e no produto da pesquisa, assim como reforça as relações de poder. Paradigmas emergentes fundamentados na teoria marxista e materialismo histórico contribuem para debater a emancipação na perspectiva crítica ao modelo hegemônico de produção de conhecimento moderno, comprometendo-se com a práxis de transformação das relações sociais a partir da compreensão das desigualdades e exclusão (SANTOS, 2009). O questionamento da distinção entre sujeito e objeto é o ponto de partida para abordar o conhecimento emancipatório, uma vez que a reciprocidade entre os atores sociais é reconhecida como essencial.

A investigação emancipatória da deficiência é uma proposta de produção científica crítica, atrelada ao paradigma emergente, politicamente fundamentada e capaz de produzir mudanças na vida das pessoas e na forma de fazer ciência (OLIVER, 1992). Trata-se, portanto, de um reposicionamento do pesquisador e da redefinição dos papeis no processo de produção científica. A investigação emancipatória se articula com o modelo social da deficiência ao revelar as condições estruturais que oprimem e negligenciam as experiências de deficiência a fim de promover a inclusão social. O compromisso político do pesquisador é ressaltado nessa perspectiva epistemológica, sendo que a implicação se dá a partir do engajamento que posiciona os atores sociais em suas relações consigo e com o outro. 
A investigação qualitativa, abordada na seção anterior, e a investigação emancipatória da deficiência compreendem a pesquisa como um ato social (MINAYO, 2014; OLIVER, 1992). Ambas reconhecem interações e relações dos atores sociais que são ativos na produção do conhecimento, sendo compreendidos como participantes com implicação ético-política que estabelecem relação de confiança, respeito e reciprocidade. Vale destacar que a relevância é uma das características da investigação emancipatória da deficiência, uma vez que se dedica a questões de justiça social e se opõe à produção científica neutra ou desinteressada (OLIVER, 1992). A pesquisa, nessa perspectiva, luta por mudanças estruturais na vida das pessoas com deficiência a fim de promover a inclusão na sociedade. A investigação emancipatória é essencialmente transformadora e esclarecedora, contribuindo para experiência coletiva e ampliação da compreensão sobre a determinação social da deficiência.

O empoderamento e emancipação das pessoas com deficiência pressupõe dar voz as suas questões que têm sido historicamente ignoradas pela sociedade opressora a fim de romper com a dominação e exclusão (OLIVER, 1992). É essencial a necessidade de diálogo e a abertura para compreender e praticar a escuta das pessoas com deficiência. O pesquisador, para isso, deve ser flexível e autocrítico em relação aos seus próprios valores, prioridades e interpretações diante da marginalização das pessoas com deficiência. A investigação emancipatória da deficiência, portanto, se refere à política do possível no enfrentamento da opressão social em qualquer nível em que ocorra.

Esta dissertação se baseia na investigação emancipatória para se pensar a valorização dos modos de ser e subjetividades dos trabalhadores da ESF, a fundamentação no modelo biopsicossocial enquanto ferramenta teórica para compreender a deficiência, a produção científica politicamente comprometida com as lutas das pessoas com deficiência e a utilização de diferentes métodos de coleta de informações para captar a complexidade do real.

A pesquisa qualitativa e a investigação emancipatória da deficiência subsidiaram a investigação realizada. As duas subseções a seguir descrevem a 
pesquisa de campo desenvolvida no Distrito "Porta do Mundo" e a pesquisa teórica sobre saúde da pessoa com deficiência do campo.

\subsection{DESCRIÇÃO DA PESQUISA EMPÍRICA}

A pesquisa empírica se dedica à face experimental e observável dos fenômenos através do trabalho em campo (DEMO, 2000). Este estudo está inserido na pesquisa intitulada "Pesquisa Avaliativa da Implantação da PNSIPCFA em distintos cenários do Brasil" que foi coordenada pelo Observatório de saúde das populações do campo, da floresta e das águas - Teia de Saberes e Práticas (OBTEIA)/Universidade de Brasília(UnB) e foi financiada pela Secretaria de Gestão Estratégica e Participativa (SGEP)/Ministério da Saúde(MS) regulamentado por meio do Termo de cooperação nำ 92/2012.

A investigação empírica foi dividida em duas fases: exploratória e sistemática, utilizando a abordagem compreensiva a qual propõe a subjetividade como fundamento do sentido da vida social e defende-a como constitutiva do social, colocando como tarefa central das ciências sociais a compreensão da realidade humana (MINAYO, 2014). A descrição dessas fases será realizada nas subseções 3.3.1 e 3.3.2. Os aspectos éticos são abordados na subsecção 3.3.3 e as informações sobre os participantes entrevistados são apresentadas na última subsecção.

\subsubsection{Fase Exploratória}

A investigação participante foi escolhida para mapear os componentes da PNSIPCFA e o desenvolvimento de ações de saúde no SUS na fase exploratória da Pesquisa Avaliativa, pois, segundo a literatura, tem como pressuposto a interação do pesquisador com os participantes da pesquisa (MINAYO, 2014). Essa modalidade de investigação, portanto, é concebida e realizada em estreita relação com um 
problema coletivo no qual os pesquisadores e os participantes representativos da situação ou do problema estão envolvidos de modo cooperativo.

Foram identificados nove territórios prioritários, nas cinco regiões geográficas do Brasil, onde a referida pesquisa foi realizada, utilizando-se os seguintes critérios: 1) possuir movimento social organizado; 2) apresentar área de conflito socioambiental; 3) existir situações ainda não pesquisadas; 4) apresentar gestores e trabalhadores comprometidos com o SUS. O Distrito "Porta do Mundo" foi selecionado como um dos territórios utilizando-se esses critérios. Vale ressaltar que nesse local o Movimento dos Atingidos por Barragens (MAB) estava atuando na situação de conflito entre comunidades locais e grandes empresas ligadas à monocultura de eucalipto e implantação de mineroduto, sendo comuns as migrações sazonais de trabalhadores para outras cidades. Antes da primeira ida ao território, foi realizado pelo OBTEIA o levantamento de dados referentes à saúde e condições de vida extraídos de Sistemas de Informação do Ministério da Saúde, Instituto Brasileiro de Geografia e Estatística (IBGE) e Atlas de Desenvolvimento Humano que compuseram a "Análise de contexto de Grão Mogol".

No Distrito "Porta do Mundo", a fase exploratória da pesquisa foi realizada de fevereiro a junho de 2015, com a participação de movimentos sociais locais. Foram realizadas quatro reuniões de articulação para inserção dos pesquisadores no campo de estudo. Nesse território, foi desenvolvida a Oficina de Planejamento da Pesquisa sob condução das referências do OBTEIA/UnB e da SGEP/MS, sendo os pesquisadores acadêmico e popular apresentados e passaram a compor o grupo de pesquisa. Foram realizadas também cinco oficinas territoriais sobre a saúde e o modo de vida nas comunidades da zona rural, sendo a primeira delas conduzida pelas referências do OBTEIA/UnB e da SGEP/MS e as outras oficinas foram coordenadas pelos pesquisadores acadêmico e popular. Além disso, ambos os pesquisadores entrevistaram coletivamente as ACS e individualmente o Secretário Municipal de Saúde e referência da Atenção Básica. Seus resultados discutem os indicadores do que ameaça e o que promove a vida no Distrito.

Vale esclarecer como se deu a escolha dos pesquisadores acadêmico e popular na fase exploratória. O primeiro foi indicado por desenvolver pesquisas sociais na região do norte de MG. O pesquisador popular foi indicado pelo MAB em 
função da sua luta por justiça social no Distrito, posicionando-se contra a gestão local. Esse perfil de militância política de ambos os pesquisadores dificultou a relação deles com a gestão local. Tornou-se necessária a intervenção das referências do OBTEIA/UnB e da SGEP/MS para mediar à relação em algumas circunstâncias.

A subseção a seguir descreve a fase sistemática da pesquisa empírica realizada no território.

\subsubsection{Fase Sistemática}

Esta fase constitui o eixo do presente estudo. A pesquisa etnometodológica foi escolhida para revelar as percepções dos trabalhadores da ESF sobre a saúde da pessoa com deficiência do campo a partir das narrativas de suas vivências e conhecimentos, pois, o desenho de cunho etnometodológico, segundo a literatura, se dá no lugar onde os fatos acontecem a fim de descrever minuciosamente a vida social por meio da compreensão dos símbolos e categorias empíricas que determinado grupo usa e aos processos que estão vivendo (MINAYO, 2014).

O desenho de cunho etnometodológico baseia-se na compreensão da realidade que é constituída por estruturas, regras, normas e conhecimentos compartilhados (MINAYO, 2014). A pesquisa etnometodológica pretende, assim, descobrir os modelos de racionalidade subjacentes à ação dos indivíduos ou grupos, preconizando técnicas de observação e investigação detalhadas das pessoas, de suas relações e de sua cultura.

O Distrito "Porta do Mundo" foi escolhido para o desenvolvimento da fase sistemática em função da implicação da mestranda com o território, uma vez que ela compunha a equipe do OBTEIA/UnB como referência nessa localidade e apoiava o Estado de Minas Gerais (MG) na implantação da RCPCD. A fase sistemática desdobrou-se da fase exploratória da pesquisa com o retorno ao território em dezembro de 2015 e permanência de seis dias. Foram utilizadas as seguintes 
técnicas: 1) observação participante; 2) entrevistas individuais semiestruturadas; 3) debates por meio da roda.

A observação participante é uma técnica na qual o pesquisador, que está em relação com os participantes da pesquisa, se coloca como observador de uma situação social (MINAYO, 2014). O pesquisador, ao participar da vida deles, relativiza o espaço social de onde provem, obtém informações sobre determinados aspectos da realidade na sua ocorrência e se torna parte do contexto sob observação, aprendendo a se colocar no lugar do outro. A aproximação entre participantes da pesquisa e pesquisador é uma virtude e não um inconveniente, podendo adentrar profundamente no grupo ao revelar seus códigos e significados mais íntimos. As informações que obtém dependem, ao final das contas, do comportamento do pesquisador e das relações que estabelece os participantes da pesquisa. O pesquisador aprende quando perguntar, assim como que perguntas fazer na hora apropriada. Nesta dissertação, compreende-se que a observação participante implica saber ouvir, escutar e ver para obter informações referentes aos fatos que ocorrem espontaneamente.

A entrevista abre a possibilidade de compreender e conhecer os dilemas e questões enfrentadas pelos indivíduos, sendo capaz de elucidar as realidades sociais (POUPART, 2008). A entrevista semiestruturada, portanto, pode ser um instrumento privilegiado de acesso à experiência dos atores, explorando aspectos afetivos e valorativos dos participantes que determinam significados pessoais de suas atitudes e comportamentos do mundo da vida. A realidade social, nesse sentido, é compreendida como um mundo de sombras e luzes em que todos os atores envolvidos revelam e escondem segredos grupais (MINAYO, 2014). Ainda que se reconheça a troca desigual entre os atores sociais na entrevista, uma vez que o pesquisador, ocupante da posição institucional de poder, se impõe ao entrevistado que é colocado na condição de objeto. Nesta dissertação, optou-se por desenvolver a entrevista semiestruturada em que, segundo a literatura, os participantes são convidados para contar histórias e o pesquisador a conduz semelhante a uma conversa informal com afinidade e de forma respeitosa, permitindo o aprofundamento em determinados aspectos referentes ao tema da pesquisa e estabelecimento de trocas intersubjetivas entre os participantes e pesquisadores. 
A roda é um espaço coletivo que propicia a integração intersujeitos, visando facilitar que os sujeitos reconheçam e expressem seus interesses e desejos (CAMPOS, 2000). Esse recurso metodológico do Paideia é identificado como potente para induzir reflexões sobre o cotidiano dos serviços e o processo de trabalho, rever conceitos e práticas, estimular as trocas entre os participantes e fortalecer a transformação da saúde. Trata-se de um método de apoio à cogestão que busca reformular os mecanismos tradicionais de gestão, potencializando a capacidade de análise dos sujeitos e os coletivos a partir de seus pontos de vista e produzindo efeitos sobre os modos de ser e proceder de trabalhadores e usuários. Nesta dissertação, a roda foi utilizada para compreender o sentido que o grupo social dá ao fenômeno social estudado, tendo como pressuposto o exercício de escuta e fala em um ambiente propício para o diálogo. A roda de conversa foi uma forma de produzir dados em que o pesquisador se inseriu como sujeito pela participação nos debates, caracterizando-se como um espaço de formação e possibilidade de estabelecer ricas trocas em conteúdo e significado.

As três técnicas de coleta de informações foram aplicadas com auxílio de roteiros com questões norteadoras, sendo que a observação participante e as entrevistas individuais semiestruturadas visaram compreender a realidade local e as percepções dos trabalhadores da ESF sobre saúde da pessoa com deficiência do campo (APÊNDICE A e B), enquanto os debates por meio da roda almejava fortalecer a discussão coletiva entre os trabalhadores da ESF (APÊNDICE C), proporcionando, segundo a literatura, a interação intersujeitos e análise das situações. O convite de participação no estudo foi realizado para todos os trabalhadores da UBS e participaram aqueles que o aceitaram. As observações, as entrevistas e a roda foram realizadas na UBS, sendo que as observações contemplaram também o território adscrito, e houve entrevista realizada na residência dos trabalhadores.

Os dados das observações e da roda foram sistematizados no diário de campo e as entrevistas foram gravadas e transcritas. O contexto sócio-histórico da produção das entrevistas foi incorporado às análises, assim como as informações provenientes das observações e da roda. Por fim, combinaram-se os dados coletados para Triangulação com a finalidade de aprofundar o conhecimento da realidade social, compreendendo-a melhor pela aproximação e exercício de olhá-la 
por vários ângulos (MINAYO, 2014). Apenas uma técnica não responderia minimamente ao objetivo desta pesquisa empírica, assim como cada uma delas por si só ainda seriam insuficientes para interpretar a realidade que supõe um processo de reconstrução. Os dados, por isso, devem ser triangulados com precisão científica.

As percepções dos trabalhadores foram sistematizadas em três grandes eixos de análise, são eles: rural, deficiência e saúde. No eixo rural, identificaram-se três categorias: contexto sócio-histórico, inserção das políticas públicas e modos de vida no povoado e na zona rural. A partir das percepções sobre deficiência, foi composto o modelo analítico por meio da tríade explicativa, com as seguintes categorias: corpo patológico, incapacidade funcional e limitada participação social. Por fim, quanto à saúde, os dados foram organizados em duas categoriais: modo de fazer saúde e acesso à saúde.

A subseção a seguir versa sobre os cuidados éticos adotados na pesquisa empírica.

\subsubsection{Considerações Éticas}

Foram respeitadas as normas estabelecidas pela Resolução CNS $\mathrm{n}^{\circ}$ 466/2012 e o projeto CAAE n 19637613.7 .0000 .0030 foi aprovado pelo Comitê de Ética em Pesquisa por meio do Parecer no 636.427 (ANEXO A). O projeto de pesquisa foi apresentado ao Secretário Municipal de Saúde que apoiou sua realização e assinou o Termo de anuência (APÊNDICE D). Os trabalhadores da ESF foram esclarecidos sobre os propósitos da pesquisa e das atividades do estudo, assim como foram informados sobre questões do anonimato, do respeito e de sua proteção ao participar no estudo. Aqueles que aceitaram participar voluntariamente da pesquisa assinaram o Termo de Consentimento Livre e Esclarecido - TCLE (APÊNDICE E). Além destas considerações, a autora teve respeito em relação aos participantes, em querer ou não participar.

A próxima seção apresenta informações sobre os participantes entrevistados na fase sistemática da pesquisa empírica. 


\subsubsection{Informações Sobre Os Participantes Entrevistados}

Os trabalhadores da ESF reconheciam a referência do OBTEIA/UnB, que se fez presente na fase exploratória, como aliada ao grupo político de oposição à gestão local. Quando ela retornou ao território na fase sistemática, eles se mostravam apreensivos e ameaçados com a coleta de dados. Tornando-se necessário reiterar os objetivos e compromissos éticos dessa pesquisa em reuniões e conversas informais a fim de estabelecer a relação de confiança entre pesquisador e trabalhador. Isto se deu, grande medida, pelo fato de a coleta de dados ter sido realizada no momento em que os trabalhadores com vínculo temporário aguardavam sua substituição por aqueles aprovados no concurso. Além disso, emergiam conflitos interpessoais na equipe em função de problemas na relação entre trabalhador e usuário. Esses fatos fizeram parte do contexto da coleta de dados e podem ter influenciado na sua produção.

Foram entrevistados 10 trabalhadores: um Médico, um Enfermeiro, dois Técnicos de Enfermagem, seis Agentes Comunitários de Saúde, dentre os quais quatro estão lotados no povoado e dois na zona rural. A maioria deles é do gênero feminino, casados, evangélicos ou católicos. A idade deles varia de 27 a 63 anos e o tempo de atuação na função de seis meses a 18 anos, sendo o vínculo funcional de seis trabalhadores estatutários e quatro temporários.

A maioria dos trabalhadores teve a experiência de ter morado e/ou trabalhado no âmbito da saúde na zona rural em algum momento de suas vidas. Geralmente, eles frequentam a zona rural no final de semana com familiares e/ou amigos. Dentre os entrevistados, apenas dois não moram na "Porta do Mundo" e sim em outro distrito de Grão Mogol. Grande parte dos trabalhadores da ESF está envolvida nos processos locais da gestão com seus grupos políticos mais defensores e críticos. Quase todos têm relação parentesco e/ou amizade íntima entre eles fora do horário de trabalho. 


\subsection{DESCRIÇÃO DA PESQUISA TEÓRICA}

A pesquisa teórica é "dedicada a reconstruir teoria, conceitos, ideias, ideologias, polêmicas, tendo em vista, em termos imediatos, aprimorar fundamentos teóricos" (DEMO, 2000). Nesta dissertação, a investigação teórica se desdobrou das dificuldades encontradas na fase sistemática. Além disso, observou-se a quase inexistência de literatura nacional e internacional sobre o tema. A fim de subsidiar a elaboração de políticas de saúde para população do campo com deficiência, para debater deficiência e ruralidades, a partir dos princípios da Atenção Básica, foram selecionados dois deles - equidade e integralidade - por serem estruturantes na PNSIPCFA, na RCPCD e na própria PNAB.

A fim de diminuir as vulnerabilidades da população do campo ao se garantir o atendimento das necessidades de saúde, destacando o fortalecimento da Atenção Básica, a PNSIPCFA foi instituída no âmbito das políticas de promoção da equidade pelo Ministério da Saúde (BRASIL, 2013). Com objetivo de promover a inclusão social das pessoas com deficiência através da identificação de suas vulnerabilidades, enfatizando essa atribuição da Atenção Básica e o desenvolvimento de ações que visam garantir o cuidado integral, a RCPCD, por sua vez, foi instituída como rede temática de atenção à saúde (BRASIL, 2012b).

Nesse sentido, foram analisadas produções acadêmicas referentes à saúde coletiva, à ruralidade, aos estudos da deficiência e à interseccionalidade por contribuírem na discussão teórico-reflexiva, sendo as informações sistematizadas nas seguintes categorias: contato preferencial na rede de atenção à saúde; concepções teóricas e equidade na saúde da população do campo; concepções teóricas e integralidade na saúde da pessoa com deficiência; e interseccionalidade nas políticas de saúde para população do campo com deficiência. 
Esta pesquisa qualitativa se fundamentou na investigação emancipatória da deficiência e foi desenvolvida em duas etapas: empírica e teórica. Vale destacar que a investigação empírica, na modalidade compreensiva, de cunho etnometodológico na fase sistemática revelou as percepções dos trabalhadores da ESF sobre a saúde da pessoa com deficiência do campo através da triangulação dos dados coletados na observação participantes, nas entrevistas individuais semiestruturadas e nos debates por meio de roda. A investigação teórica se concentrou no aprofundamento do debate sobre as concepções da deficiência e das ruralidades nas políticas da população do campo e da pessoa com deficiência. A inserção da interseccionalidade nas políticas de saúde para as situações de dupla vulnerabilidade também foi discutida na pesquisa teórica.

Os resultados e discussão desta pesquisa são apresentados no próximo capítulo desta dissertação através de dois artigos. 


\title{
4. RESULTADOS E DISCUSSÃO
}

Este capítulo está dividido em duas seções com um artigo em cada uma, sendo o primeiro intitulado "Equidade e integralidade na Atenção Básica: reflexões sobre política de saúde para população do campo com deficiência" e o segundo intitulado "Saúde da pessoa com deficiência do campo: o que dizem os trabalhadores da Atenção Básica?".

\subsection{ARTIGO TEÓRICO - EQUIDADE E INTEGRALIDADE NA ATENÇÃO BÁSICA: REFLEXÕES SOBRE POLÍTICA DE SAÚDE PARA POPULAÇÃO DO CAMPO COM DEFICIÊNCIA}

Revista: Physis (A ser submetido)

\begin{abstract}
Autores: Bárbara Lyrio Ursine'; Éverton Luís Pereira" ; Fernando Ferreira Carneiro"';

' Fisioterapeuta, especialista em Saúde da Família e Mestranda em Saúde Coletiva da Universidade de Brasília, Distrito Federal. E-mail: barbaraursine@yahoo.com.br
\end{abstract}

" Docente do Departamento de Saúde Coletiva da Universidade de Brasília, Distrito Federal. E-mail: everton.epereira@gmail.com

III Pesquisador e Diretor da Fiocruz Ceará. E-mail: fernandocarneirofiocruz@gmail.com

\section{Equidade e integralidade na Atenção Básica: reflexões sobre política de saúde para população do campo com deficiência}

Resumo: A fim de subsidiar a elaboração de políticas de saúde para população do campo com deficiência, o objetivo deste artigo é debater deficiência e ruralidades a partir de dois princípios da Atenção Básica - equidade e integralidade - os quais são estruturantes na Política Nacional de Saúde Integral para as Populações do Campo, da Floresta e das Águas, na Rede de Cuidados à Pessoa com Deficiência e na Política Nacional da Atenção Básica. As concepções de ruralidade e modelo social da deficiência, que emergiram do debate crítico ao modelo hegemônico, fundamentaram as políticas de saúde para população do campo e pessoas com deficiência. A dupla vulnerabilidade da população do campo com deficiência não é discutida na literatura nacional e tem sido pouco abordada expressamente em documentos oficiais dessas políticas. O espaço na agenda política foi conquistado através das políticas supracitadas e a Atenção Básica se fortaleceu como 
contato preferencial na rede de atenção à saúde, fundamentando-se na equidade e integralidade. A inserção da interseccionalidade nas políticas de saúde pode contribuir para repensá-las na perspectiva das desigualdades múltiplas, revelando a realidade social e propiciando a ampliação do acesso e a qualificação do atendimento à população do campo com deficiência.

Palavras-chave: Pessoas com deficiência; Saúde da população rural; Atenção Primária à Saúde; Equidade em Saúde; Integralidade em Saúde.

\section{Considerações iniciais}

A relevância da Atenção Básica em saúde foi defendida internacionalmente no Relatório Dawson e na Declaração de Alma Ata (STARFIELD, 2002). O Relatório Dawson (1920) trata da organização do sistema de serviços de saúde fundamentada em diferentes níveis de atenção, sendo o primeiro nível a base sobre a qual se constitui a rede de serviços e se ressalta a importância do médico generalista, das ações preventivas e da regionalização. A Declaração de Alma Ata (1978) aponta os cuidados primários em saúde como fundamentais nos sistemas de saúde, subsidiando muitos países quanto às mudanças necessárias para reorganização do modelo de atenção médica convencional em uma atenção primária à saúde mais ampla que se baseia nas necessidades da população.

No Brasil, a Atenção Básica ganha destaque político organizativo na década de 1970, associado ao processo de redemocratização do país, quando surge o movimento da reforma sanitária brasileira em defesa de um novo sistema de saúde que possibilitasse, a todos os brasileiros, o acesso aos serviços de forma integral e hierarquizada (MENDES, 2011). Destaca-se que na Política Nacional da Atenção Básica (PNAB), a Estratégia Saúde da Família (ESF) é prioritária para reorganização do modelo de atenção à saúde (BRASIL, 2012a).

A Atenção Básica é central na organização das políticas de saúde para a consolidação dos princípios do Sistema Único de Saúde (SUS). No caso da população do campo, a Atenção Básica se mostra ainda mais relevante na garantia de acesso à saúde com equidade, conforme ressaltado na Política Nacional de Saúde Integral para as Populações do Campo, da Floresta e das Águas ${ }^{8}$ -

\footnotetext{
${ }^{8}$ Populações do campo, da floresta e das águas são compostas por grupos que habitam ou usam reservas extrativistas em áreas florestais ou aquáticas, sejam eles agricultores familiares, trabalhadores rurais assentados ou acampados, assalariados e temporários que residam ou não no campo (BRASIL, 2013). Nesse grupo estão ainda as comunidades tradicionais, como as ribeirinhas, quilombolas, populações atingidas por barragens, entre outras. Essas populações têm seus modos de vida, produção e reprodução social relacionados predominantemente com a terra.
} 
PNSIPCFA (BRASIL, 2013). Paralelamente, a Atenção Básica é apontada como importante componente da Rede de Cuidados à Pessoa com Deficiência (RCPCD) por desenvolver ações estratégicas para a ampliação do acesso e da qualificação da atenção à saúde (BRASIL, 2012b). Essas políticas específicas de saúde da população do campo e da pessoa com deficiência são recentes e estão se consolidando no âmbito do SUS.

A população do campo no Brasil apresenta os maiores índices de mortalidade infantil, de incidência de endemias, de insalubridade e de analfabetismo, condições de pobreza e restrições ao acesso aos bens e serviços indispensáveis à vida (BRASIL, 2013). Também na área rural, a falta de esgoto e de água encanada e potável é bem maior do que na área urbana, o que pode estar associado à ocorrência de doenças caracterizadas por sintomas gastrointestinais.

Paralelamente, as pessoas com deficiência em todo o mundo apresentam piores condições de saúde, níveis mais baixos de escolaridade, menor participação econômica, maior exposição à violência, maior dependência e restrições à participação social, e taxas de pobreza mais elevadas em comparação as pessoas sem deficiência (OMS, 2012). Em parte, isso se deve ao fato de enfrentarem barreiras no acesso aos bens e serviços fundamentais. Ainda que a deficiência esteja relacionada a desvantagens, nem todas as pessoas as sofrem igualmente, ou seja, tal condição afeta desproporcionalmente populações vulneráveis.

O presente artigo sugere a intersecção entre esses dois eixos de desigualdade fundamentando-se na perspectiva de interseccionalidade ${ }^{9 i}$, transcendendo os limites da análise de apenas um desses eixos e revelando invisibilidades perpetuadoras de injustiças. Nesse sentido, este artigo se propõe a discutir a relevância da Atenção Básica do ponto de vista interseccional para se repensar a saúde da população do campo com deficiência. A interseccionalidade é um conceito analítico potente para interpretar a realidade e atuar adequadamente sobre ela, visando a sua transformação a partir da compreensão do

\footnotetext{
${ }^{9}$ Kimberl Crenshaw introduziu o debate conceitual sobre a discriminação interseccional ao se referir sobre os direitos humanos das mulheres negras (ALONSO, 2010). A interseccionalidade busca capturar as consequências estruturais e dinâmicas da interação entre dois ou mais eixos da subordinação determinadas pelo sexismo, racismo e patriarcalismo, evitando distorções e invisibilidades no trato de casos de discriminação e possibilitando compreender o fenômeno discriminatório de forma mais abrangente e complexa.
} 
entrecruzamento dos eixos de subordinação que produzem desigualdades (MELLO e GONÇALVES, 2010). A abordagem das políticas de saúde da população do campo com deficiência na perspectiva da interseccionalidade, no entanto, não tem sido observada na literatura.

A escolha desse tema se deve às dificuldades encontradas na fase sistemática da pesquisa avaliativa da implantação da PNSIPCFA, na qual foram reveladas as percepções dos trabalhadores da ESF sobre a saúde da população do campo com deficiência. Além disso, observou-se a quase inexistência de literatura nacional e internacional sobre o tema. O objetivo deste artigo é debater, a partir dos princípios da Atenção Básica, deficiência e ruralidades a fim de subsidiar a elaboração de políticas de saúde para população do campo com deficiência.

Para o debate, foram selecionados dois princípios da Atenção Básica equidade e integralidade - por serem estruturantes na PNSIPCFA, na RCPCD e na própria PNAB. A PNSIPCFA foi instituída no âmbito das políticas de promoção da equidade pelo Ministério da Saúde com o objetivo de diminuir as vulnerabilidades da população do campo ao se garantir o atendimento das necessidades de saúde, destacando o fortalecimento da Atenção Básica (BRASIL, 2013). A RCPCD, por sua vez, foi instituída como rede temática de atenção à saúde a fim de promover a inclusão social das pessoas com deficiência através da identificação de suas vulnerabilidades, enfatizando essa atribuição da Atenção Básica, e desenvolvimento de ações que visam garantir o cuidado integral (BRASIL, 2012b). Ressalta-se que para efeitos deste artigo, Atenção Básica e Atenção Primária à Saúde serão consideradas termos equivalentes.

Produções acadêmicas referentes à saúde coletiva, à ruralidade, aos estudos da deficiência e à interseccionalidade foram selecionadas na literatura por contribuírem na discussão teórico-reflexiva proposta neste artigo, sendo apresentada em quatro seções: contato preferencial na rede de atenção à saúde; concepções teóricas e equidade na saúde da população do campo; concepções teóricas e integralidade na saúde da pessoa com deficiência; e interseccionalidade nas políticas de saúde para população do campo com deficiência. 


\title{
Atenção Básica: contato preferencial na rede de atenção à saúde
}

A Atenção Básica deve ser o contato preferencial dos usuários por ser principal porta de entrada no sistema de saúde e ordenadora das redes de atenção à saúde (BRASIL, 2012a; MENDES, 2011), podendo ser compreendida como:

\begin{abstract}
um conjunto de ações de saúde, no âmbito individual e coletivo, que abrange a promoção e a proteção da saúde, a prevenção de agravos, o diagnóstico, o tratamento, a reabilitação, redução de danos e a manutenção da saúde com o objetivo de desenvolver uma atenção integral que impacte na situação de saúde, na autonomia das pessoas e nos determinantes e condicionantes de saúde das coletividades (BRASIL, 2012a, p.19).
\end{abstract}

Por isso, ela se fundamenta nos princípios da integralidade, equidade, acesso universal, vínculo, continuidade do cuidado, resolutividade, responsabilização, humanização e da participação social. Esses princípios foram propostos como resultados da experiência acumulada na consolidação do SUS, expressando o compromisso político em garantir o direito à saúde para melhorar o nível de saúde das pessoas. Na Atenção Básica, utilizam-se tecnologias de cuidado complexas e variadas, priorizando suas intervenções segundo critérios de frequência, risco, resiliência, vulnerabilidade e imperativo ético das necessidades de saúde.

Nesse nível de atenção, a ESF é prioritária para expansão, consolidação e qualificação da Atenção Básica no Brasil, uma vez que induz a reorientação do processo de trabalho, baseando-se nos seus princípios, além de propiciar vantajosa relação custo-efetividade (BRASIL, 2012a). O Núcleo de Apoio à Saúde da Família (NASF), por sua vez, deve atuar de maneira integrada e apoiando os trabalhadores da ESF, compartilhando as práticas e saberes em saúde, bem como, atuando diretamente no apoio matricial e no território sob responsabilidade deles.

A PNAB, PNSIPCFA e RCPCD apresentam o princípio da integralidade na esfera do cuidado do usuário e da articulação entre todos componentes e pontos de atenção da rede de saúde (BRASIL, 2012a; BRASIL, 2012b; BRASIL, 2013). As equipes multidisciplinares desenvolvem ações intra e intersetoriais pela ESF e NASF, ofertando assistência sob a lógica interdisciplinar a fim de qualificar o atendimento às necessidades de saúde da população do campo e das pessoas com deficiência na Atenção Básica. 
Essa compreensão de integralidade na dimensão "focalizada" e "ampliada" nas políticas de saúde corrobora com a literatura que discute a superação da fragmentação do cuidado na micro e macropolítica de saúde (CECÍLIO, 2001). A dimensão "focalizada" está no âmbito do cuidado do usuário em que a equipe multiprofissional propicia escuta qualificada e atendente suas necessidades de saúde no espaço da micropolítica de saúde, enquanto a dimensão "ampliada" opera na rede complexa e articulada composta por serviços de saúde e outras instituições para oferecer melhoria nas condições de vida dos usuários no nível da macropolítica de saúde. Nesse sentido, a integralidade na micro é refletida na macro, estabelecendo-se entre si relações articuladas, complementares e dialéticas.

A integralidade pode ser discutida em pelo menos três conjuntos de sentidos: características das políticas ou respostas governamentais aos problemas de saúde; modo de organização das práticas e dos serviços de saúde; atributos das práticas de saúde (MATTOS, 2001). As políticas de saúde da população do campo e pessoa com deficiência se referem às respostas governamentais a problemas específicos primeiro sentido da integralidade. Ambas as políticas reconhecem o papel da Atenção Básica em articular ações preventivas com assistenciais e a PNAB explicita a responsabilidade sanitária pelas situações e problemas de saúde mais frequentes numa certa população. O segundo sentido da integralidade se refere à organização dos serviços, sendo que as políticas de saúde da Atenção Básica, população do campo e pessoa com deficiência versam sobre novas formas de pensar e fazer saúde a partir da reorganização tecnológica para se estabelecer relações horizontais, rompendo com a imposição vertical das ações. O terceiro sentido é voltado para práticas de saúde, podendo ser identificado nas políticas de saúde supracitadas a fim de apreender as necessidades de saúde de forma ampliada e prudente ao desenvolver práticas intersubjetivas na dimensão dialógica e de ofertar ações sintonizadas com o contexto sócio-cultural do usuário.

A promoção da equidade é um princípio fundamental da PNAB, da PNSIPCFA e da RCPCD (BRASIL, 2012a; BRASIL, 2012b; BRASIL, 2013). O desenvolvimento de ações que contribuam para o enfrentamento da desigualdade em saúde para população do campo cabe à Atenção Básica, valorizando os processos de (re)produção social e respeitando a especificidades de gênero, geração, cor, raça, etnia e orientação sexual (BRASIL, 2012a; BRASIL, 2013). Na 
Atenção Básica, devem ser observadas as especificidades inerentes e indispensáveis para garantir o acesso com equidade às pessoas com deficiência (BRASIL, 2012b). A literatura situa esse princípio no contexto de produção sóciohistórica das desigualdades sociais que são evitáveis e injustas, implicando atendimento diferenciado por meio de intervenção do Estado (CECÍLIO, 2001).

Nas políticas de saúde da Atenção Básica, da população do campo e da pessoa com deficiência, a equidade é compreendida em pelo menos dois sentidos, sendo um deles na perspectiva da igualdade em saúde e o outro no âmbito do julgamento e intervenção situacional (CAMPOS, 2006). A promoção da equidade reafirma a justiça social como princípio fundamental em que se tratam desigualmente os desiguais conforme suas necessidades, admitindo o tratamento singular para cada situação quando se baseia nas necessidades individuais, a fim de atingir o ideal da máxima igualdade possível ao se eliminar desvantagens e diferenças negativas. Há de avançar na superação das iniquidades na sociedade capitalista, reduzindo ou eliminando diferenças em saúde resultantes de fatores considerados ao mesmo tempo evitáveis e injustos por meio de políticas sociais e econômicas.

$\mathrm{Na}$ literatura, equidade equivale à justiça no que se refere à situação de saúde e condições de vida uma vez que, idealmente, as pessoas têm direito a possibilidade justa de realizar seu pleno potencial de saúde e que ninguém estará em desvantagem para gozar esse direito (WHITEHEAD, 1992). A inequidade se refere a diferenças que são desnecessárias e evitáveis, além de consideradas injustas, assumindo, assim, uma dimensão ética e moral. As políticas de equidade visam reduzir ou eliminar diferenças em saúde resultantes de fatores considerados ao mesmo tempo evitáveis e injustos, sendo direcionadas para as raízes dos problemas.

A literatura nega a possibilidade de haver integralidade e equidade sem a universalidade do acesso garantida (CECÍLIO, 2001). Nesse sentido, a garantia de acesso é um princípio elementar da PNAB, PNSIPCFA e RCPCD (BRASIL, 2012a; BRASIL, 2012b; BRASIL, 2013). A Atenção Básica é o componente central da PNSIPCFA e da RCPCD para garantir à população do campo e às pessoas com 
deficiência o acesso ${ }^{10}$ à saúde uma vez que é caracterizada como porta de entrada aberta e preferencial, acolhendo os usuários e promovendo a vinculação e corresponsabilização pela atenção às suas necessidades de saúde. Assim, a Atenção Básica deve possibilitar o acesso universal e contínuo a serviços resolutivos nas condições e no tempo adequado, realizando práticas de regulação articuladas entre os pontos de atenção e componentes das redes de atenção à saúde (MENDES, 2011).

A fim de facilitar o acesso do usuário na dimensão sócio-organizacional se utiliza a vulnerabilidade como critério para priorização das atividades desenvolvidas pela Atenção Básica (BRASIL, 2012b). A vulnerabilidade resulta de um conjunto de fragilidades individuais e precariedades sociais que atingem um sujeito cujas condições de vida e saúde são influenciadas ou determinadas por aspectos sóciohistóricos (AYRES, CALAZANS, SALETTI FILHO e FRANÇA-JÚNIOR, 2006).

A dupla vulnerabilidade da população do campo com deficiência não é discutida na literatura nacional e tem sido pouco abordada em documentos oficiais da RCPCD ou PNSIPCFA. Todavia, observa-se que essa população sofre a desigualdade de modo único e qualitativamente diferente, sendo impossível analisálo a partir de uma mera soma das vulnerabilidades. A população do campo com deficiência sofre discriminação qualitativamente diversa daquela vivida pela população da zona urbana com deficiência ou pela população do campo sem deficiência, porque cada pessoa ou grupo populacional experimenta distintas opressões e privilégios. Nesse sentido, a interseccionalidade possibilita compreender as relações de poder e dinâmicas discriminatórias, revelando a realidade social.

${ }^{10}$ Starfield (2002) destaca diferenças entre acesso e acessibilidade, apesar de se considerar a complementaridade desses conceitos. Para ela acessibilidade refere-se a características da oferta, sendo o acesso a forma como as pessoas percebem a acessibilidade. 


\section{Rural: concepções teóricas e equidade na saúde}

Neste artigo, as denominações "Campo" e "Rural" são consideradas sinônimas. Os conceitos de rural são diretamente influenciados pelo contexto sóciohistórico e econômico no Brasil (BEZERRA, BACELAR, MIRANDA e SILVA, 2013). Até o século XVIII, o rural foi o principal espaço de produção e de vida, estando predominantemente relacionado com atividades agrícolas, enquanto a economia urbana era quase inexistente (MEDEIROS, QUINTANS e ZIMMERMANN, 2014). No século $X X$, o Brasil passou por rápida urbanização na qual o processo de êxodo rural foi induzido pela revolução industrial fundamentada no modelo de produção capitalista. Houve também intensa modernização agrícola com concentração de terra, expansão do monocultivo, uso de agrotóxico e fertilizante sintético. Essas mudanças interferiram nas relações sociais e de trabalho no campo, transformando as noções de rural e urbano.

A partir da década de 40, o Brasil adotou a definição sobre delimitação dos espaços em rurais e urbanos (MEDEIROS, QUINTANS e ZIMMERMANN, 2014). Instituto Brasileiro de Geografia e Estatística (IBGE) ainda mantém essa divisão binária que leva em consideração as legislações municipais para definir os territórios. Urbanos, portanto, são aqueles que vivem nos perímetros definidos pelas Câmaras Municipais, independentemente de qualquer outra consideração. As áreas rurais são externas aos perímetros urbanos de cidades e vilas. Nesse sentido, o espaço rural é entendido como periférico, residual e sinônimo de atraso, em oposição ao urbano que significa progresso (BEZERRA, BACELAR, MIRANDA e SILVA, 2013). O rural está se reduzindo em termos populacionais nessa concepção tradicional e hegemônica (MEDEIROS, QUINTANS e ZIMMERMANN, 2014).

$\mathrm{Na}$ regulamentação legal do rural brasileiro, constata-se o vazio institucional conferido a esse espaço, sendo que se priorizaram intervenções nos espaços urbanos a fim de ampliar o crescimento urbano-industrial enquanto os espaços rurais ficam à margem no modelo de desenvolvimento (BEZERRA, BACELAR, MIRANDA e SILVA, 2013). A literatura, no entanto, tem discutido sobre a ressignificação do rural, trazendo para agenda política as demandas de melhoria das condições de quem lá permanece a fim de manter os modos tradicionais de vida. 
Evidencia-se essa revalorização quando a Constituição de 1988 diferencia as concepções de propriedade rural e urbana: enquanto a função social da propriedade urbana está relacionada à moradia e ao bem-estar, o campo está ligado à produção (MEDEIROS, QUINTANS e ZIMMERMANN, 2014).

A concepção de ruralidade emerge do debate crítico ao modelo hegemônico de desenvolvimento no campo em que o rural foi reconhecido numericamente como relevante e diversificado sociologicamente (BEZERRA, BACELAR, MIRANDA e SILVA, 2013). Nessa concepção, o camponês excluído historicamente do processo de desenvolvimento se organizou politicamente para defender seus direitos e o reconhecimento de seus modos singulares de viver. A zona rural, portanto, é compreendida não apenas como um lugar de trabalho e produção, mas também é um lugar de vida e expressão cultural da população, que se caracteriza pela heterogeneidade e multiplicidade.

A ruralidade reconhece a interdependência e complementariedade entre zona rural e urbana na produção social uma vez que esses espaços não são opostos (MEDEIROS, QUINTANS e ZIMMERMANN, 2014). As noções de campo e urbano, compreendidas como categoriais simbólicas determinadas por representações socais, expressam visões de mundo e valores distintos, tratando-se de um processo dinâmico de constante reestruturação da cultura a partir da incorporação de novos valores e costumes (Quadro 1). Nessa visão contemporânea, rural se expressa enquanto forma territorial de vida social, onde a relação com a natureza é forte e a atividade agropecuária é dominante, mas não é exclusiva (BEZERRA, BACELAR, MIRANDA e SILVA, 2013). 
Quadro 1 - Concepções teóricas do rural na literatura

Tradicional e

\section{hegemônica}

- Espaçode produção.

- Predominantemente relacionada com atividades agrícolas

- Êxodo rural.

- IBGE: urbanox rural.

- Periférico, residual e sinônimo de atraso.

\section{Ruralidade}

- Debate crítico ao modelo hegemônico de desenvolvimento.

- Luta em defesa dos direitos e pelo reconhecimento dos modos devida.

- Numericamente relevante e sociologicamente diversificado

- Lugar de trabalho e produção + lugar de vida e expressão cultural.

- Urbano e rural: interdependentes e complementares

Ao longo do tempo, as políticas públicas se fundamentam na visão homogênea da população brasileira e realidade nacional, tornando-as inadequadas para atender as necessidades da zona rural. As políticas de saúde para o campo estiveram historicamente associadas aos interesses econômicos ligados à garantia de mão de obra sadia para a exploração dos recursos naturais (CARNEIRO, 2007). O Fundo de Assistência ao Trabalhador Rural (Funrural), por exemplo, permitia formalmente 0 acesso dos trabalhadores rurais, com carteira de trabalho assinada, à assistência à saúde tipicamente urbana e curativa. As ações curativas e não universais com caráter desintegrado, centralizado e urbano desenvolvidas no âmbito da saúde para população do campo estão alinhadas com a concepção hegemônica de rural. Essa fragmentação pode ainda contribuir para promover iniquidade em saúde, pois as opressões daqueles menos favorecidos e os privilégios dos grupos populacionais hegemônicos se perpetuam na sociedade capitalista.

A descontinuidade e fragmentação das ações em saúde reproduziram as elevadas taxas de morbidade e mortalidade, uma vez que as condições de vida são desfavoráveis para quem vive no campo e estão associadas com as barreiras de acesso às políticas públicas (BRASIL, 2013). Por meio da PNSIPCFA, o Estado reconhece sua dívida histórica ao expressar o compromisso político em garantir o direito à saúde, intervindo para reduzir riscos e agravos decorrentes dos processos de trabalho e das tecnologias agrícolas. Ressalta-se que a PNSIPCFA se fundamenta na necessidade de superação do modelo de desenvolvimento socioeconômico, rompendo com a lógica de produção capitalista que degrada o meio ambiente e prejudica a saúde. No que se refere ao acesso aos serviços de 
saúde, a política prevê que as vulnerabilidades sejam reduzidas por meio de ações integrais em saúde.

A PNSIPCFA está alinhada com a concepção de ruralidade, pois suas diretrizes valorizam os processos de produção social e respeitam as singularidades nos modos de vida, valores e cultura de cada grupo social (Quadro 2). A promoção da equidade é expressamente citada na finalidade da PNSIPCFA, relacionando-se ao desenvolvimento humano e à qualidade de vida dessas populações por meio de melhoria do nível de saúde decorrente da implementação de políticas intersetoriais baseadas na geração de emprego e renda, acesso à terra, provimento de saneamento ambiental, habitação, soberania e segurança alimentar e nutricional, educação, cultura, lazer e no transporte digno (BRASIL, 2013). Ainda que a literatura sobre ruralidade e a PNSIPCFA considerem as diversidades da população do campo, a deficiência tem sido pouco mencionada .

Quadro 2 - Políticas de saúde para população do campo

\section{Políticas de saúde anteriores}

- Alinhada com a concepção hegemônica do rural.

- Inadequadas para atender necessidades dazona rural.

- Historicamente associadas aos interesses econômicos.

- Ações aurativas e não universais com caráter desintegrado, centralizado e urbano.

\section{PNSIPCFA}

- Alinhada com a concepção de ruralidade.

- Reconhecimentoda dividahistórica.

- Necessidade de superação do modelo de desenvolvimento.

- Prevê que as vulnerabilidades sejam reduzidas por meio de ações integrais em saúde.

- Promoção da equidade: desenvolvimento humano e qualidade de vida com açõesintersetorias. 


\section{Deficiência: concepções teóricas e integralidade na saúde}

A literatura discute vários significados da deficiência os quais envolvem explicações fortemente influenciadas por valores e condutas sociais que, por sua vez, são determinadas pelo contexto histórico. Desses significados, emergem ao menos dois modelos teóricos da deficiência: biomédico e social.

O modelo biomédico aborda a deficiência na perspectiva individual como condição essencialmente negativa, infortúnio, tragédia pessoal e drama familiar, estando fortemente arraigada no determinismo biológico (DINIZ, 2007). A deficiência é determinada naturalmente, ou seja, como consequência direta do impedimento. As ações curativas e de reabilitação para os corpos patológicos são prioritárias para reverter ou atenuar os sinais de anormalidade. Diante do fracasso na intervenção terapêutica, explica-se 0 isolamento social das pessoas com deficiência que geralmente se restringem à intimidade da esfera privada da vida, sendo confinadas ao ambiente doméstico e, muitas vezes, institucionalizadas.

Os estudos sobre deficiência, desenvolvidos no Reino Unido, na década de 1970, e Estados Unidos, posteriormente, fundamentaram o surgimento do modelo social que questiona a soberania do discurso biomédico frente à deficiência, uma vez que se opõe à ideia de deficiência como anormalidade (DINIZ, 2007). Deficiência se distingue de exploração, resiste à tese de que é condição natural de um corpo com lesões e se contrapõe a noção de tragédia pessoal, sendo compreendida como uma forma de opressão (ABBERLEY, 1987). O impedimento é determinado no contexto sócio-econômico em que as pessoas vivem, podendo ser compreendidos como parte da diversidade humana (BARNES e OLIVER, 1993) e estilos de vida (DINIZ, 2007). Os teóricos do modelo social, portanto, rompem com a relação de causalidade entre impedimento corporal e deficiência como desvantagem natural, compreendendo a deficiência ser entendida como opressão ao corpo e não como uma variação corporal universalmente indesejável. As desvantagens sociais, econômicas, ambientais e psicológicas experimentadas pelas pessoas com impedimento são reconhecidas, portanto a deficiência passa a existir quando 
aspectos da vida prática e estrutura social geram tais desvantagens e exclusão das pessoas (ABBERLEY, 1987). Nesse sentido, experiência de deficiência não é resultado de lesões, mas do contexto social hostil à diversidade corporal que impede a plena participação social.

A teoria do modelo social fundamenta-se no materialismo histórico, compreendendo a deficiência como consequência do sistema capitalista e explicando a segregação social pelo marxismo, uma vez que se rompe com ideal de sujeito produtivo: disfuncional e incapaz (DINIZ, 2007; BARNES e OLIVER, 1993). Além da perspectiva teórica, o ativismo dos movimentos de pessoas com deficiência e a entrada dos estudos sobre deficiência no meio acadêmico conduzem a guinada política em defesa de justiça social. Teóricos do modelo social advertem que as pesquisas sobre deficiência estavam sendo desenvolvidas inadequadamente de maneira a reproduzir a marginalização e opressão, portanto, não estavam contribuindo para melhorar a vida das pessoas (OLIVER, 1992). Diante do questionamento dos princípios positivistas, a investigação emancipatória da deficiência foi proposta em uma visão crítica das pesquisas na área que reposicionou 0 pesquisador e redefinam os papeis na pesquisa científica, ressaltando o compromisso político do investigador.

Assim, o tema da deficiência deixa de ser pautado exclusivamente pela biomedicina como problema que afeta uma minoria da população (Quadro 3), sendo percebido como importante fenômeno sócio-político contemporâneo com implicações para toda sociedade e reconhecido como alvo de ações políticas e intervenções do Estado por meio de proteção social e reparação das desigualdades (BARNES e OLIVER, 1993). Nessa perspectiva, a responsabilidade de reduzir as desvantagens foi transferida para sociedade, sendo que nem todo corpo com impedimento vivencia a opressão, tornando fundamentais mudanças nos conceitos e atitudes, uma vez que se ressalta a questão do manejo coletivo da deficiência na promoção da justiça social. 
Quadro 3 - Concepções teóricas de deficiência na literatura

\section{Modelo biomédico}

- Perspectiva individual.

- Condição essencialmente negativa, infortúnio, tragédia pessoal e drama familiar.

- Determinismo biológico e desvantagem natural: deficiência é consequência direta do impedimento.

- Reverter ou atenuar os sinais de anormalidade.

- Isolamento social.

\section{Modelo social}

- Perspectiva social

- Forma deopres̃ão: exclusão.

- Ruptura da relação de causalidade: impedimento é determinado no contexto socio-econômico, Diversidade humana.

- Reconhecimento das desvantagens experimentadas

- Fundamentação no materialismo histórico.

- Ativismo dos movimentos de pessoa com deficiência e acadêmicos

Na evolução das reflexões sobre a deficiência na Organização Mundial de Saúde (OMS) e, consequentemente, na incorporação dessas propostas nas ações de saúde, ressalta-se a importância da publicação da Classificação Internacional de Lesão, Deficiência e Handicap (ICIDH) pela para unificação da terminologia biomédica sobre lesões e deficiências, propiciando a padronização para fins comparativos e implantação de políticas de saúde (DINIZ, 2007). No entanto, a ICIDH resgatou conceitos e terminologias perniciosos e aproximou a deficiência das doenças. Sua revisão foi denominada Classificação Internacional de Funcionalidade, Incapacidade e Saúde (CIF), tentando integrar os modelos médico e social. A abordagem na CIF é biopsicossocial, baseando-se nos componentes de funções e estruturas do corpo, atividade e participação social.

No movimento de revisar a trajetória do modo como a deficiência vem sendo historicamente tratada, a Convenção sobre os Direitos das Pessoas com Deficiência, aprovada pela Organização das Nações Unidas (ONU) e promulgada com equivalência de emenda constitucional no Brasil (BRASIL, 2009), dialoga com o modelo biomédico e social de deficiência e consagrando as pessoas com deficiência como "aquelas que têm impedimento de natureza física, intelectual ou sensorial, os quais, em interação com diversas barreiras, podem obstruir sua participação plena e efetiva na sociedade com as demais pessoas". A Convenção cita as difíceis situações as quais as pessoas com deficiência enfrentam e as formas múltiplas ou 
agravadas de discriminação as quais estão sujeitas. A responsabilidade do Estado em assegurar o acesso aos serviços de saúde é mencionada na Convenção com vistas a eliminar barreiras e equipar oportunidades, sendo que tais serviços estejam o mais possível de suas comunidades, inclusive na zona rural.

A saúde da pessoa com deficiência foi historicamente negligenciada pelo poder público, deixando à sociedade civil tal responsabilidade através da caridade e filantropia (CAMPOS, SOUZA e MENDES, 2015). Na concepção da deficiência como consequência natural do impedimento, o tratamento curativo e reabilitador adequado é elementar para melhoria das condições de vidas das pessoas, destacando-se o papel da Atenção Especializada por desenvolver ações nas áreas de medicina, genética e de reabilitação, ainda que pouco engajados em garantir o cuidado integral. Vale ressaltar que o discurso biomédico foi ganhando autoridade para explicar e tratar as patologias e enfermidades numa lógica intervencionista campanhista-sanitarista, medicalizante e reabilitadora a fim de que os corpos desviantes possam funcionar próximo da normalidade e participar dos vários espaços com as demais pessoas.

Antes de a RCPCD ser instituída, eram desenvolvidas ações pontuais e desarticuladas, as quais não contemplavam as necessidades das pessoas com deficiência, restringindo o cuidado à Atenção Especializada organizada por modalidade de reabilitação (CAMPOS, SOUZA e MENDES, 2015). Essa organização fragmentada do sistema de saúde e hierarquização com serviços mais "complexos" compromete a garantia do cuidado integral (CECÍLIO, 2001). Ainda que a RCPCD esteja ancorada no modelo biomédico ao desenvolver ações focalizadas nos problemas individuais, identificaram-se elementos condizentes com o modelo social da deficiência (Quadro 4). A compreensão da deficiência como manifestação da diversidade humana e forma de opressão exige desenvolver prática interdisciplinares e ampliar o escopo das ações em saúde desenvolvidas no âmbito do SUS, destacando-se o componente da Atenção Básica por promover a integração sistêmica das ações e serviços de saúde e garantir a integralidade do cuidado. Nessa concepção, as ações intersetoriais são colocadas em evidência em função de suas potencialidades para superar a fragmentação das políticas sociais, integrando-as e respeitando suas especificidades a fim de melhorar a saúde das pessoas com deficiência. 
Quadro 4 - Políticas de saúde para pessoa com deficiência

- Alinhada com o modelo biomédico: tratamento curativo e reabilitador, destacando-se o papel da Atenção Especializada.

- Historicamente negligenciada pelo poder público.

- Pouco engajadas em garantir o cuidado integral.

- Ações pontuaise desaticuladas.

- Lógica intervencionista campanhistasanitarista, medicalizante e reabilitadora;
- Ancorada no modelo biomédico com elementos do modelosocial.

- Práticas interdisciplinares e ampliação das ações em saúde, destacando o componente da Atenção Básica.

- Evidência as ações intersetoriais para superar a fragmentação das políticas sociais e promoção do direito às diferençase aceitação.

- Integralidade dos saberes com apoio matricial e com identificação das vulnerabilidadese necessidades

$\mathrm{Na}$ RCPCD, a promoção do respeito às diferenças e aceitação de pessoas com deficiência é ressaltada a fim de construir a intersetorialidade para promoção da saúde e prevenção de doenças em parceria com organizações governamentais e da sociedade civil. Esse arranjo organizativo visa, ainda, contemplar a integralidade dos saberes com fortalecimento do apoio matricial e identificação das vulnerabilidades dos usuários e suas necessidades. Ainda que a literatura sobre o modelo social e a RCPCD reconheçam a atenção à saúde das pessoas com deficiência como meio de proteção social e reparação das desigualdades, ambos não abordam suas necessidades e especificidades a depender se vivem na zona rural ou não.

\section{Interseccionalidade nas políticas de saúde para população do campo com deficiência}

Os princípios da integralidade e da equidade têm sido bastante discutidos na literatura nacional e internacional (CAMPOS, 2006; CECÍLIO, 2001; MATTOS, 2001). O cuidado integral em saúde implica a recusa ao reducionismo, o estabelecimento de relações entre sujeitos e a abertura para o diálogo a fim de ampliar as percepções das necessidades individuais e diversificar as dimensões de respostas aos problemas identificados. As necessidades de saúde e os recursos singulares para respondê-las devem estar disponíveis para promoção da equidade em saúde na Atenção Básica, podendo este princípio ser traduzido como igualdade, uma vez que se respeitam as diversidades e reduzem as desigualdades sociais consideradas injustas. Ambos os princípios podem ser compreendidos como imagem-objetivo para fortalecimento da Atenção Básica e, consequentemente, consolidação do SUS, ou seja, indicam características desejáveis do sistema de saúde e suas práticas, contrastando-as com realidade atual. 
As concepções de ruralidade e modelo social da deficiência, ainda que pouco utilizadas na literatura nacional e internacional, fundamentaram as políticas de saúde no Brasil para população do campo e pessoas com deficiência, respectivamente, que emergiram do debate crítico ao modelo hegemônico na luta pela proteção social (BEZERRA, BACELAR, MIRANDA e SILVA, 2013; MEDEIROS, QUINTANS e ZIMMERMANN, 2014; DINIZ, 2007; ABBERLEY, 1987; BARNES e OLIVER, 1993; OLIVER, 1992). O espaço na agenda foi conquistado através RCPCD e PNSIPCFA que valorizam o papel da Atenção Básica no contato preferencial na rede de atenção à saúde, fundamentando-se no princípio da equidade para saúde da população rural e no princípio da integralidade para pessoas com deficiência. $O$ entrelaçamento entre as desigualdades múltiplas, por outro lado, têm sido pouco explorado. A interação entre as diferenças dos grupos populacionais têm sido negligenciada e a integração entre as políticas não acontece, resultando na perpetuação das injustiças, devido à invisibilidade das estruturas de subordinação (ALONSO, 2010).

A intersecção se refere aos vários eixos de desigualdades, tais como, a ruralidade e a deficiência, que transcorrem de modo independente, no entanto, pode haver múltiplas e variadas intersecções, ou seja, entrecruzamentos (MELLO e GONÇALVES, 2010). Além de explorar as consequências das situações diferenciadas, a literatura destaca a necessidade das politicas públicas considerarem a interseccionalidade. Para isso, é necessário se pensar políticas mais justas e inclusivas através da desconstrução da perspectiva universalistas que privilegiam um grupo hegemônico (ALONSO, 2010). Além disso, os privilégios dos grupos populacionais dominantes na sociedade capitalista (homem, urbano, sem deficiência etc) precisam ser reconhecidos para que as desigualdades sejam enfrentadas.

O discurso da atenção à saúde é dominado pela população do campo sem deficiência que se sobrepõe as demais pessoas que vivem na zona rural como, por exemplo, as pessoas com deficiência as quais têm suas diferenças ignoradas. Paralelamente, a população da zona urbana é hegemônica quando se pensa se faz saúde da pessoa com deficiência, desconsidera-se o modo de vida e relações estabelecidas em contextos rurais. A perspectiva interseccional contesta esse papel de centralidade, uma vez que subsidia o reconhecimento das distintas e complexas experiências da população do campo, emergindo a necessidade de dar visibilidade 
às várias diferenças entre pessoas que vivem na zona rural e urbana para se evitar invisibilidades. Nesse sentido, a interseccionalidade é potente para quebrar paradigmas hegemônicos e analisar conjunturas sócio-históricas em que grupos e indivíduos submetem-se a desigualdades (MELLO e GONÇALVES, 2010). Vale ressaltar que a necessidade de se revelar as singularidades na discriminação e nos contextos sociais em relação ao status da população do campo com deficiência.

A literatura sobre políticas de equidade tem discutido sobre a inserção da interseccionalidade a fim de contribuir para repensá-las na perspectiva das desigualdades múltiplas (ALONSO, 2010). A PNSIPCFA reconhece as diversidades da população do campo para redução das vulnerabilidades em saúde, no entanto a deficiência é pouco citada dentre elas. A RCPCD coloca as necessidades em saúde como questão central para garantir a integralidade do cuidado às pessoas com deficiência, tendo como princípio a diversificação das estratégias de cuidado, porém não menciona a população do campo. Primeiramente, as politicas deveriam reconhecer que as desigualdades estão interligadas e que uma pessoa pode sofrer mais do que outra (ALONSO, 2010). Nesse sentido, as politicas precisam considerar que nem sempre as desigualdades são totalmente independentes.

\section{Considerações finais}

O reconhecimento da promoção da equidade e integralidade do cuidado dentre os princípios estruturantes das políticas específicas de saúde para população do campo e para pessoas com deficiência são imagem-objetivo para o fortalecimento da Atenção Básica com vistas a garantir a atenção à saúde da população do campo com deficiência. A PNSIPCFA e a RCPCD se fundamentam, respectivamente, nas concepções de ruralidade e modelo social da deficiência que emergiram do debate crítico ao modelo hegemônico na luta pela proteção social. Diante da negligência histórica do poder público no que tange à saúde da população do campo e da pessoa com deficiência, a PNSIPCFA e a RCPCD representam a conquista do espaço na agenda, valorizando o papel da Atenção Básica no contato preferencial na rede de atenção à saúde. O entrelaçamento entre essas desigualdades múltiplas, por outro lado, tem sido pouco explorado por essas políticas, resultando na perpetuação das injustiças, em função da sua parca invisibilidade. 
A Convenção sobre os Direitos das Pessoas com Deficiência, por exemplo, corrobora com a interseccionalidade, pois aborda expressamente formas múltiplas e agravadas de discriminação, ao tratar de políticas públicas para mulheres e meninas com deficiência. Essa incorporação de direitos humanos no ordenamento jurídico brasileiro é um avanço, ainda que incipiente, na abordagem de discriminações múltiplas. Paralelamente, a PNSIPCFA dialoga com a intersecção entre ruralidade e gênero ao preconizar ações em saúde integrais voltadas para mulher a fim de reduzir as vulnerabilidades da população do campo, reconhecendo a diversidade da mulher camponesa ao destacar a temática da violência e direitos sexuais e reprodutivos.

Vale destacar que é necessário ter o eixo da deficiência na própria política de saúde da pessoa com deficiência, assim como, considerar a assimetria entre pessoas com e sem deficiência quando for se referir a outras políticas de equidade para grupos em situações de desigualdade, dentre eles a população do campo. Paralelamente, o eixo de subordinação referente à ruralidade deve estar na própria PNSIPCFA, assim como, deve ser reconhecida as vulnerabilidades de viver na zona rural e na urbana quando for se referir a outras políticas de equidade para grupos em situações de desigualdade, dentre eles as pessoas com deficiência.

Devem ser desenvolvidas pesquisas que abordem a interação entre as formas de desvantagens que geram opressão conjuntamente, coexistindo e reforçando-se mutuamente na produção das desigualdades sociais. Essa interpretação da realidade pode subsidiar a ampliação do acesso e qualificação do atendimento às pessoas com deficiência do campo que vivem em uma situação de dupla vulnerabilidade. O desafio é implantar políticas de saúde que garantam os princípios da Atenção Básica, considerando contextos específicos e experiências distintas na perspectiva da interseccionalidade.

\section{Referências}

ABBERLEY, P. The Concept of Oppression and the Development of a Social Theory of Disability.Disability,Handicap \& Society, v. 2, n. 1, p. 5 - 19, 1987. 
ALONSO, A. A introdução da interseccionalidade em Portugal: Repensar as políticas de igualdade(s). Revista Crítica de Ciências Sociais, Coimbra, v. 90, p. 2543. 2010.

AYRES,J.R.C.M.;CALAZANS,G.J.; SALETTI FILHO,H.C., FRANÇA-JÚNIOR, I. Risco, vulnerabilidade e práticas de prevenção e promoção da saúde. In: SOUZA, G.W.; MINAYO, M.C.S.; AKERMAN, M.; DRUMOND JUNIOR, M.; CARVALHO, Y.M (Org). Tratado de Saúde Coletiva. Rio de Janeiro: Hucitec/Fiocruz, 2006. p. 375-417.

BARNES, C; OLIVER, M. Disability: A Sociological Phenomenon Ignored by Sociologists, 1993. Disponível em: <http://disabilitystudies.leeds.ac.uk/files/library/Barnes-soc-phenomenon.pdf>. Acesso em: 12 abril. 2016.

BEZERRA, M.L.; BACELAR, T.; MIRANDA, C.; SILVA, H. Concepções da ruralidade contemporânea: as singularidades brasileiras. Brasília: IICA, 2013, 476p.

BRASIL. Ministério da Saúde.Secretaria de Atenção à Saúde. Departamento de Atenção Básica. Política Nacional de Atenção Básica. Brasília: Ministério da Saúde, 2012 a.110 p.

BRASIL. Ministério da Saúde. Portaria no 793, de 24 de abril de 2012. Institui a Rede de Cuidados à Pessoa com Deficiência. 2012 b. Disponível em: <http://bvsms.saude.gov.br/bvs/saudelegis/gm/2012/prt0793 2404 2012.html>.

Acesso em: 2 dez. 2015.

BRASIL. Ministério da Saúde. Secretaria de Gestão Estratégica e Participativa. Departamento de Apoio à Gestão Participativa. Política Nacional de Saúde Integral das Populações do Campo e da Floresta. Brasília: Ministério da Saúde, 2013. 48 p.

BRASIL. Presidência da República. Decreto n 6.949, de 25 de agosto de 2009. Promulga a Convenção Internacional sobre os Direitos das Pessoas com Deficiência e seu Protocolo Facultativo assinados em Nova lorque, em 30 de março de 2007. Disponível em: <http://www.planalto.gov.br/ccivil 03/ ato20072010/2009/decreto/d6949.htm> .Acesso em: 2 out. 2015. 
CAMPOS, G. W. S. Reflexões temáticas sobre equidade e saúde: o caso do SUS. Saude soc., São Paulo, v. 15, n. 2, p. 23-33, 2006.

CAMPOS, M.F.; SOUZA, L.A.P.; MENDES, V.L.F. A rede de cuidados do Sistema Único de Saúde à saúde das pessoas com deficiência. Interface: Botucatu, Botucatu, v. 19, n. 52, p. 207-10, 2015.

CARNEIRO, F. F. A saúde no campo: das políticas oficiais à experiência do MST e de famílias de "bóias frias" em Unaí, Minas Gerais. 2005. 143 p. Tese (Doutorado em Ciência Animal) - Escola de Veterinária, Universidade Federal de Minas Gerais, Belo Horizonte, 2007.

CECÍLIO, L.C.O. As necessidades de saúde como conceito estruturante na luta pela integralidade e equidade na atenção em saúde. In: PINHEIRO, R; MATTOS R. (Org.) Os sentidos da integralidade na atenção e no cuidado à saúde. Rio de Janeiro: IMS/ UERJ, Abrasco, 2001. p. 113-26.

DINIZ, D. O que é deficiência. São Paulo: Editora Brasiliense, 2007. 96 p.

MATTOS, R. A. Os sentidos da integralidade: algumas reflexões acerca de valores que merecem ser defendidos. In: PINHEIRO, R; MATTOS R. (Org.) Os sentidos da integralidade na atenção e no cuidado à saúde. Rio de Janeiro: IMS/ UERJ, Abrasco, 2001. p. 39-64.

MEDEIROS, L.S.; QUINTANS, M. T. D.; ZIMMERMANN, S. A. Rural e urbano no Brasil: marcos legais e estratégias políticas. Contemporânea - Revista de Sociologia da UFSCar, São Carlos, v. 4, n. 1, p. 117-42, 2014.

MELLO, L; GONÇALVES. E. Diferença e interseccionalidade: notas para pensar práticas em saúde. Revista do programa de pós-graduação em ciências da UFRN, Natal, v. 11, n.2, p. $163-73,2010$.

MENDES, E.V. As redes de atenção à saúde. Brasília: Organização PanAmericana da Saúde, 2011.549 p.

OLIVER, M. Changing the social relations of research production? Disability\&Society, v. 2, n. 7, p.101-14, 1992. 
OMS. Relatório mundial sobre a deficiência. São Paulo: SEDPcD, 2012. 334 p.

STARFIELD, B. Atenção primária: equilíbrio entre necessidades de saúde, serviços e tecnologia. Brasília: UNESCO/Ministério da Saúde, 2002.726p.

WHITEHEAD, M. The concepts and principles of equity in health. International Journal of Health Services, Westport, v. 22, p. 429-445, 1992. 


\title{
4.2. ARTIGO EMPÍRICO - SAÚDE DA PESSOA COM DEFICIÊNCIA DO CAMPO: O QUE DIZEM OS TRABALHADORES DA ATENÇÃO BÁSICA?
}

Revista: Interface (Artigo submetido)

\author{
Carneirolli. \\ Autores: Bárbara Lyrio Ursine'; Éverton Luís Pereira" ; Fernando Ferreira
}

' Fisioterapeuta, especialista em Saúde da Família e Mestranda em Saúde Coletiva da Universidade de Brasília, Distrito Federal. E-mail: barbaraursine@yahoo.com.br

" Docente do Departamento de Saúde Coletiva da Universidade de Brasília, Distrito Federal. E-mail: everton.epereira@gmail.com

III Pesquisador e Diretor da Fiocruz Ceará. E-mail: fernandocarneirofiocruz@gmail.com

\section{Saúde da pessoa com deficiência do campo: o que dizem os trabalhadores da Atenção Básica?}

Este estudo objetivou analisar as percepções dos trabalhadores da Estratégia Saúde da Família sobre a saúde da pessoa com deficiência do campo. Trata-se de uma pesquisa de abordagem qualitativa com o desenho de cunho etnometodológico. Foi realizada observação participante e debates por meio da roda, com registro em diário de campo, e entrevistas semiestruturadas em uma Unidade Básica de Saúde de Grão Mogol, Minas Gerais. Na análise, combinaram-se os dados coletados para Triangulação. Os resultados evidenciam que as políticas desenvolvimentistas e inserção das políticas públicas estão incidindo sobre a saúde das populações do campo. A deficiência está ancorada no modelo biomédico e a dimensão da caridade se ressalta nas ações em saúde. $O$ desenho da Rede de Cuidados à Pessoa com Deficiência deve ser repactuado a fim de enfrentar as barreiras de acesso à saúde.

Palavras-chave: Pessoas com deficiência; Saúde da população rural; Atenção Primária à Saúde; Acesso aos Serviços de Saúde; Sistema Único de Saúde.

\section{People with disability that live in the countryside health: what workers Primary Care say?}

This study aimed to analyze the perceptions of health workers of the Family Health Strategy about people with disability that live in the countryside health. This is a qualitative research with an ethno methodological design. The data was collected through Participant observation, Circle discussions, Field journal and semi-structured interviews at the Primary Health Care Service in the city of Grão Mongol, state of Minas Gerais. The Triangulation analysis was used. The results show that the development policies and integration of public policies are focusing on the health of populations in the countryside. Disability is anchored in the biomedical model and the size of the charity is emphasized in the health actions. The Health Care Network for People with Disabilities should be renegotiated to address the health access barriers.

Keywords: Disabled persons; Rural health; Primary Health Care; Health services accessibility; Unified Health System. 


\section{Introdução}

No Sistema Único de Saúde (SUS), a Atenção Básica é um importante componente da Rede de Cuidados à Pessoa com Deficiência (RCPCD) por desenvolver ações estratégicas para a ampliação do acesso e da qualificação da atenção à saúde ${ }^{1}$. Na Política Nacional de Saúde Integral para as Populações do Campo, da Floresta e das Águas (PNSIPCFA), a relevância da Atenção Básica também é ressaltada a fim de garantir o acesso com equidade para população do campo $^{2}$. Destaca-se que no âmbito da Atenção Básica, a Estratégia Saúde da Família (ESF) é uma das prioridades para reorganização do modelo de atenção à saúde no Brasil ${ }^{3}$.

As atividades da ESF devem ser desenvolvidas de acordo com as necessidades de saúde da população, priorizando-se as intervenções segundo critérios de frequência, risco, resiliência e vulnerabilidade ${ }^{3}$. A vulnerabilidade resulta de um conjunto de fragilidades individuais e precariedades sociais que atingem um sujeito cujas condições de vida e saúde são influenciadas ou determinadas por aspectos sociais e históricos ${ }^{4}$. Nesse sentido, o presente artigo aborda as condições de vulnerabilidade das pessoas com deficiência que vivem no campo as quais apresentam dupla desvantagem na vida social, compreendendo-as na perspectiva da interseccionalidade ${ }^{5}$.

Pessoas com deficiência são "aquelas que têm impedimento de natureza física, intelectual ou sensorial, os quais, em interação com diversas barreiras, podem obstruir sua participação plena e efetiva na sociedade com as demais pessoas". Essa denominação foi consagrada pela Convenção sobre os Direitos das Pessoas com Deficiência, promulgada com equivalência de emenda constitucional no Brasil ${ }^{6}$ e dialoga com o modelo biomédico e social de deficiência ${ }^{7,8}$.

Em relação às pessoas do campo com deficiência, a escassa e limitada literatura sugere que essas pessoas têm a condição de saúde mais comprometida do que a população do campo sem deficiência ${ }^{9}$. Apesar, de tanto as pessoas com deficiência, quanto aquelas que vivem no campo relatarem muitos dos mesmos tipos de impedimentos, a deficiência parece exacerbar as barreiras de acesso à saúde ${ }^{10}$. 
As pessoas com deficiências do campo parecem viver em maior desvantagem quanto às suas condições de saúde, uma vez que a deficiência e a vida no campo estão associadas a menor número de oportunidades de educação e emprego, à falta de transporte público acessível e a dificuldades comunicacionais e no acesso a serviços de saúde ${ }^{11}$.

Ressalta-se que as denominações de "Campo" e "Rural" são consideradas neste artigo como sinônimos em uma perspectiva mais ampla, a qual corrobora com a concepção de ruralidade. Essa concepção aborda a diversidade do rural, bem como reconhece o fato de ser um lugar de vida e expressão cultural da população, extrapolando a noção de ser apenas de um espaço de produção ${ }^{12}$.

Diante desse contexto, o objetivo deste artigo é analisar as percepções dos trabalhadores da ESF sobre a saúde da pessoa com deficiência do campo, valorizando-se seus modos de ser e subjetividades.

\section{Método}

Trata-se de uma pesquisa com abordagem metodológica qualitativa na modalidade compreensiva, a qual está inserida no Projeto de Pesquisa intitulado "Pesquisa Avaliativa da Implantação da PNSIPCFA em distintos cenários do Brasil" coordenada pelo Observatório de saúde das populações do campo, da floresta e das águas - Teia de Saberes e Práticas (OBTEIA). Essa pesquisa foi desenvolvida em nove territórios prioritários, sendo que em um deles foi realizada em duas etapas, a saber: fase exploratória com investigação participante e fase sistemática com cunho etnometodológico $^{13}$. Este artigo apresenta os resultados da fase sistemática do projeto.

\section{Campo de estudo}

Na fase exploratória, a coleta de dados se deu em nove territórios prioritários, escolhidos por meio dos seguintes critérios: 1) possuir movimento social organizado; 2) apresentar área de conflito socioambiental; 3) existir situações ainda não pesquisadas; 4) apresentar gestores e trabalhadores comprometidos com o SUS. Utilizando-se esses critérios, o Distrito "Porta do Mundo"- nome fictício - foi selecionado como um dos territórios. O critério para selecionar esse território na fase sistemática foi a implicação da primeira autora deste artigo com o território, uma vez 
que ela compõe a equipe do OBTEIA como referência nessa localidade e apoia o Estado de Minas Gerais (MG) na implantação da RCPCD.

"Porta do Mundo" está localizada no município de Grão Mogol, norte de MG, distando $51 \mathrm{~km}$ da sede municipal por acesso de terra e $101 \mathrm{~km}$ por acesso com pavimentação asfáltica. Grão Mogol ${ }^{14}$ possui uma população de 15.024 habitantes, com área territorial de $3.885,294 \mathrm{~km}^{2}$ e densidade populacional de $3,87 \mathrm{hab} / \mathrm{km}^{2}$. A população cadastrada pela Unidade Básica de Saúde (UBS) do Distrito é estimada em 2.000 habilitantes. Esta UBS, único estabelecimento de saúde existente na localidade, dispõe de uma equipe da ESF - formada por um Médico, um Enfermeiro, um Técnico de Enfermagem, sete Agentes Comunitários de Saúde (ACS) - com equipe de Saúde Bucal - formada por um Dentista e um Técnico de saúde bucal. A UBS também conta ainda com dois trabalhadores ligados aos Serviços Gerais, dois Recepcionistas, três Técnicos de Enfermagem e um trabalhador na Farmácia.

\section{População do estudo e coleta das informações}

A fase exploratória da pesquisa foi realizada de fevereiro a junho de 2015 , com a participação de movimentos sociais locais. Essa fase baseou-se no desenho da investigação participante ${ }^{13}$ para mapear os componentes da PNSIPCFA e o desenvolvimento de ações de saúde no âmbito do SUS. Foram realizadas quatro reuniões de articulação para inserção dos pesquisadores no campo de estudo. Nesse território, foi desenvolvida a Oficina de Planejamento da Pesquisa, cinco Oficinas na zona rural, uma entrevista coletiva com ACS e duas entrevistas individuais com gestores locais da saúde. Seus resultados discutem os indicadores do que ameaça e promove a vida no Distrito.

A fase sistemática desdobrou-se da fase exploratória da pesquisa com o retorno ao território em dezembro de 2015, a partir de um desenho de cunho etnometodológico $^{13}$, com a perspectiva epistemológica da investigação emancipatória da deficiência ${ }^{8}$. Foram utilizadas as seguintes técnicas: 1) observação participante; 2) entrevistas individuais semiestruturadas; 3) debates por meio da roda $^{15}$. As três técnicas foram aplicadas com auxílio de roteiros com questões norteadoras, sendo que as duas primeiras visavam compreender a realidade local e as percepções dos trabalhadores sobre saúde da pessoa com deficiência do campo, 
enquanto a terceira técnica almejava fortalecer a discussão coletiva, proporcionando a interação intersujeitos e análise das situações.

O convite de participação no estudo foi realizado para todos os trabalhadores da UBS e participaram aqueles que o aceitaram. As observações, as entrevistas e a roda foram realizadas na UBS, sendo que as observações contemplaram também o território adscrito, e houve entrevista realizada na residência dos trabalhadores.

\section{Análise das informações}

Os dados das observações e da roda foram sistematizados no diário de campo e as entrevistas foram transcritas. O contexto sócio-histórico da produção das entrevistas foi incorporado às análises, assim como as informações provenientes das observações e da roda. Por fim, combinaram-se os dados coletados para Triangulação ${ }^{13}$.

As percepções dos trabalhadores foram sistematizadas em três grandes eixos de análise, são eles: rural, deficiência e saúde. No eixo rural, identificaram-se três categorias: contexto sócio-histórico, inserção das políticas públicas e modos de vida no povoado e na zona rural. A partir das percepções sobre deficiência, foi composto o modelo analítico por meio da tríade explicativa, com as seguintes categorias: corpo patológico, incapacidade funcional e limitada participação social. Por fim, quanto à saúde, os dados foram organizados em duas categoriais: modo de fazer saúde e acesso à saúde.

Nessa pesquisa, foram observadas as normas estabelecidas pela Resolução CNS no 466/2012 e o projeto CAAE no 19637613.7 .0000 .0030 foi aprovado pelo Comitê de Ética em Pesquisa.

\section{Resultados e Discussão}

No início da fase sistemática, os trabalhadores da ESF se mostravam apreensivos e ameaçados com a coleta de dados, tornando-se necessário reiterar os objetivos e compromissos éticos dessa pesquisa em reuniões e conversas informais a fim de estabelecer a relação de confiança entre pesquisador e trabalhador. Isto se deu, grande medida, pelo fato de a coleta de dados ter sido realizada no momento em que os trabalhadores com vínculo temporário aguardavam 
sua substituição por aqueles aprovados no concurso. Além disso, emergiam conflitos interpessoais na equipe em função de problemas na relação entre trabalhador e usuário. Esses fatos fizeram parte do contexto da coleta de dados e podem ter influenciado na sua produção.

Foram entrevistados um Médico, um Enfermeiro, dois Técnicos de Enfermagem e seis ACS - dentre os quais quatro estão lotados no povoado e dois na zona rural -, totalizando 10 trabalhadores. A maioria deles é do gênero feminino, casados, católicos ou evangélicos. A idade deles varia de 27 a 63 anos. O tempo de atuação na função varia entre seis meses a 18 anos e o vínculo funcional é predominantemente temporário, seguido dos estatutários. A maioria dos trabalhadores mora na "Porta do Mundo" e está envolvida nos processos locais da gestão com seus grupos políticos mais defensores e críticos.

\section{Percepções sobre o rural}

A maioria dos trabalhadores teve a experiência de ter morado e/ou trabalhado no âmbito da saúde na zona rural em algum momento de sua trajetória. Mesmo aqueles que não moram na "Porta do Mundo" geralmente frequentam o campo no final de semana com familiares e/ou amigos. O povoado do Distrito está localizado às margens da BR-251 e concentra os comércios, os serviços e edificações de públicas (onde não há plantação de eucalipto). Quanto à zona rural, situa-se distante do povoado, em média, $15 \mathrm{~km}$.

\subsection{Contexto sócio-histórico}

As falas dos trabalhadores revelam o contexto sócio-histórico local da "Porta do Mundo" e da região do norte de MG. Com base na literatura disponível, notou-se que suas histórias de vida podem ser reconhecidas em três ciclos de desenvolvimento.

O primeiro ciclo se iniciou nos anos 70, quando a vegetação nativa das chapadas foi substituída pela monocultura de eucaliptos e pinus, e os territórios foram retirados das pessoas que viviam na zona rural ${ }^{16}$, obrigando-as a se tornar trabalhadores assalariados. O segundo ciclo foi impulsionado pela produção de carvão vegetal e pelo processamento da madeira de eucalipto nas serrarias locais. A grande fazenda, situada na região do povoado, passou a atrair pessoas de diversos 
locais à procura de trabalho a partir da década de 1990. Por fim, o terceiro ciclo se deu a partir de 2006, na preparação da "Porta do Mundo" para a extração do minério de ferro e seu transporte por meio do mineroduto ${ }^{16}$. Nesse ciclo, trabalhadores foram atraídos novamente para o povoado.

"(O Distrito) é a porta do mundo", afirmou um trabalhador, se referindo ao fato do local atrair cidadãos locais e de outros lugares, a fim de usufruir do crescimento econômico ou contribuir para o desenvolvimento. Ressalta-se que o norte de MG foi tradicionalmente estigmatizado como lugar de pobreza e miséria, tornando-a alvo de políticas desenvolvimentistas em função da necessidade de superação do subdesenvolvimento imputada a essa região ${ }^{17}$. No entanto, essas políticas provocaram à ocupação do território e a consequente retirada da população ${ }^{16}$, assim como, a reestruturação do sistema de produção daqueles que viviam na zona rural.

\subsection{Inserção das políticas públicas no Distrito}

Observou-se que os ciclos desenvolvimentistas se correlacionam diretamente com a inserção das políticas públicas na "Porta do Mundo". A partir do segundo ciclo desenvolvimentista, foram implantadas políticas de saúde, educação, previdência e assitência social para atender aqueles que migraram para o Distrito, contemplando tanto o povoado, quanto a zona rural. Diante da dificuldade de acesso à educação para quem vive no campo, a estratégia para se chegar à escola no povoado é o transporte escolar. Segundo os trabalhadores, o tempo total de deslocamento pode chegar a quatro horas, fazendo, portanto, que o horário de saída e chegada dos escolares em seus domicílios seja diferente entre aqueles que moram no povoado e na zona rural, mesmo que estudem no mesmo turno.

No terceiro ciclo desenvolvimentista na "Porta do Mundo", houve incremento de políticas para o acesso à energia elétrica e aos serviços de telefonia e comunicação de dados no povoado e no campo. Além disso, banheiros foram construídos nos domicílios da zona rural. O tratamento da água, a coleta de lixo e o calçamento das ruas, entretanto, restringem-se ao povoado. As ruas com calçamento são aquelas próximas à UBS, à escola, ao ginásio poliesportivo, ao campo de futebol e ao Posto Policial. Destaca-se que "Porta do Mundo" foi reconhecida em 2013 como Distrito de Grão Mogol. 


\subsection{Modos de vida no povoado e na zona rural}

A UBS da "Porta do Mundo" é identificada pela Secretaria de Saúde como um estabelecimento de saúde da zona rural, em uma concepção tradicional e hegemônica descrita na literatura, como um lugar de atraso, o qual precisa de intervenção para se modernizar ${ }^{18}$. O campo legalmente foi definido por oposição e exclusão às áreas consideradas urbanas $^{12}$, ou seja, todo espaço de um município que não corresponder às áreas urbanas é considerado como rural.

Identificou-se um paradoxo na concepção de rural na "Porta do Mundo", uma vez que os trabalhadores da ESF dividem seu território em sete micro áreas, sendo quatro no povoado com 1.311 habitantes e três na zona rural com 691 habitantes. Ressalta-se que os usuários têm frequentemente domicilio em ambas as localidades. Segundo a narrativa dos trabalhadores, é comum usuários saírem da zona rural e se mudar para o povoado quando necessitam de cuidado intensivo e buscam melhores condições de vida.

A motocicleta é o meio de transporte mais utilizado para se transitar entre o povoado e a zona rural, demonstrando que o modo de viver no campo está em transformação, conforme relato:

[...]E a maioria, hoje teve um avanço, porque antigamente na roça, antes você falava em roça já se pensava o que? Vaca, cavalo[...] Hoje os cavalos virou moto, em tudo quanto é região, as pessoas não tem mais animal, não tem cavalo nem burro. Eles têm moto.. os rapazinhos vão de charrete pra trabalhar pra comprar uma moto, e vai, trabalha e compra a moto, entende?[...] Modernizou muito a roça, em todos os sentidos [...] (Entrevistado 8)

As falas dos trabalhadores da ESF corroboram com a literatura no que se refere ao reconhecimento do meio rural como o espaço de produção relacionado à atividade agropecuária e artesanal $^{18}$ como fonte de renda. Nesse sentido, os trabalhadores questionam quem vive no campo e não cultiva horta nem cria animais: "Eu acho muito ruim a pessoa morar na zona rural e não aproveitar a terra" (Entrevistado 5). Os trabalhadores da ESF também reconhecem o campo como lugar de (re)produção social ao falar dos singulares modos de vida das comunidades da zona rural. Esse reconhecimento da diversidade sociológica do campo corrobora com a concepção de ruralidade ${ }^{12}$ : 
[...]cada localidade nós temos alguma coisa. Por exemplo, o jeito de falar do pessoal do Lamarão [...] Ele pode chegar aqui e ter cem pessoas lá fora, se ele abrir a boca, você vê que é um Lamarão; porque tem um sotaque diferente, um jeito de falar [...] Já o pessoal do São Francisco, para te cumprimentar ele vai dar uma abaixadinha assim. Eu acho que isso é uma questão cultural de cada comunidade[...] (Entrevistado 5)

Ainda, os trabalhadores da ESF são unânimes ao afirmar que se vive melhor na "Porta do Mundo" atualmente, sendo que alguns deles destacam as melhorias nos modos de vida no campo - "Tudo que você tem na cidade, você tem na roça agora[...] Então assim, a época das vacas magras já passou" (Entrevistado 8) ; ainda que reconheçam desafios a serem superados.

\section{Percepções sobre deficiência}

Diferentemente dos outros tópicos abordados, o tema deficiência não surgiu espontaneamente nas entrevistas nem nas conversas. Portanto, os resultados a seguir apresentados foram decorrentes de questões colocadas pela pesquisadora que instigaram os trabalhadores da ESF, revelando que essa não é uma questão que faça parte das preocupações cotidianas deles. A deficiência física foi mais frequentemente abordada pelos trabalhadores, mas também houve menção às deficiências auditiva e intelectual, sendo esta última tratada como transtorno mental.

A deficiência é narrada pelos trabalhadores da ESF na perspectiva individual como infortúnio - "Graças a Deus na minha área nunca teve deficiente..." (Entrevistado 4) -, tragédia pessoal e drama familiar - "[Ser deficiente] pode acabar com a vida..." (Entrevistado 4). Essa forma de se pensar corrobora com o modelo biomédico da deficiência ${ }^{19}$ o qual ressalta seu determinismo biológico e é criticada pelo modelo social ${ }^{7}$ o qual destaca o manejo coletivo da deficiência, e por este motivo, reivindica mudanças nos conceitos e atitudes referentes ao tema.

Ao mesmo tempo os trabalhadores da "Porta do Mundo" reconhecem necessidades específicas das pessoas com deficiência e se organizam para atendêlas, identificando suas vulnerabilidades conforme as diretrizes da PNAB e RCPCD ${ }^{1 ; 3}$. A partir das percepções dos trabalhadores da ESF, identificou-se o tripé das categorias analíticas (corpo patológico, incapacidade funcional e limitada participação social) que explicam da deficiência na perspectiva dos mesmos. 
Fundamentando-se nos saberes biomédicos, as necessidades das pessoas com deficiência são centrais nesse tripé - "Tem um probleminha que precisa ser olhado mais de perto" (Entrevistado 2). Para eles, a pessoa com perda auditiva que faz uso de aparelho de amplificação sonora, por exemplo, não é reconhecida como pessoa com deficiência, pois não apresenta restrição funcional nem na participação social, estando dispensada de intervenções de saúde específicas.

A equipe da ESF percebe ainda, como noção de deficiência, a existência de problemas sociais que se relacionam com a transgressão dos padrões considerados normais na "Porta do Mundo", tais como: uso de álcool e outras drogas, desemprego, gravidez na adolescência e pobreza. De acordo com a concepção cultural da deficiência na literatura, a anomalia humana e a experiência de opressão social podem ser determinadas por crenças, expectativas sociais e situação econômica de uma sociedade ${ }^{20}$.

\subsection{Corpo patológico}

Observou-se que a deficiência é percebida pelos trabalhadores com estranhamento, dada a visão de anormalidade quanto às diferenças e marcas dos corpos das pessoas com deficiência:

[...] aquela pessoa aérea, e assim parece que não tem discernimento nenhum[...] A forma dele andar ou de se expressar ou conversar[...]Você olha pra pessoa e ela é assim parece ter nada, mas assim na forma como ela conversa com você, você vê que ela tem algum tipo de deficiência pela fala, forma, gesto[...] (Entrevistado 6).

Ainda, para os entrevistados, deficiência e diagnóstico patológico estão intrinsecamente relacionados: "[A pessoa estava] sem patologia nenhuma além da deficiência auditiva." (Entrevistado 1). As falas dos trabalhadores apontam para a importância das ações curativas e de reabilitação para esses corpos desviantes no âmbito da atenção à saúde. Segundo o modelo biomédico da deficiência ${ }^{19}$, tais ações são prioritárias para reverter ou atenuar os sinais da anormalidade.

O modelo social da deficiência surgiu em oposição ao modelo biomédico e transfere a responsabilidade de adaptação do ambiente para a sociedade, resistindo à ideia de deficiência como anormalidade e defendendo que a opressão social não decorreria de suas limitações corporais. O tema da deficiência, portanto, além de ser 
pautado pela biomedicina, também deve ser alvo de ações políticas e intervenções do Estado por meio de proteção social e reparação de desigualdades ${ }^{7}$.

\subsection{Incapacidade funcional}

Para os trabalhadores da ESF, a incapacidade funcional se relaciona diretamente com a dependência parcial ou total do corpo patológico nas atividades cotidianas: "Não daquela deficiência que a pessoa é inoperante que a pessoa não pode fazer nada, mas tem uma coisa diferente" (Entrevistado 2). Eles afirmam que essa dependência do corpo patológico no desempenho funcional se dá em função de desvantagens biológicas:

[...]É pessoa que não consegue desenvolver suas atividades de vida diária ou de vida diária instrumental sozinha, não tem independência para isso, por alguma limitação física ou mental[...] (Entrevistado 1).

Esse relato corrobora com o modelo biomédico no qual a deficiência é determinada naturalmente como consequência direta do corpo com impedimento ${ }^{19}$. O modelo social da deficiência inova na concepção de que a deficiência é produto da opressão social, explicitando-se a relação de desigualdade imposta por ambientes com barreiras sociais a corpos com impedimentos. Nessa perspectiva, nem todo corpo com impedimento vivencia a opressão pela deficiência ${ }^{7}$.

\subsection{Limitada participação social}

Os trabalhadores da ESF associam deficiência aos "acamados" que não necessariamente estão limitados ao leito, podendo estar restritos ao domicilio e ao convívio com a família. A pessoa com deficiência geralmente não frequenta a escola nem trabalha fora, ainda que desenvolva habitualmente atividades domésticas. No modelo biomédico da deficiência, restringe-se o corpo com impedimentos à intimidade da esfera privada da vida sendo que o seu confinamento se justifica pela desvantagem natural ${ }^{19}$.

Enquanto o afastamento do convívio social é naturalizado pelos trabalhadores, o isolamento social acompanhado de denúncia de falta, omissão ou abuso dos pais ou do responsável gera incômodo, mobilizando a equipe a intervir com o Conselho Tutelar no atendimento as pessoas em situação de risco psicossocial para defender seus direitos fundamentais. No modelo biomédico da 
deficiência, o isolamento social e a institucionalização são explicados pelo fracasso da intervenção terapêutica no corpo patológico ${ }^{19}$.

Na Convenção sobre os Direitos das Pessoas com Deficiência, a deficiência é definida expressamente como restrição de participação, sendo produto da interação dos impedimentos corporais com um ambiente com barreiras à diversidade corporal ${ }^{6}$. Nessa perspectiva, a sociedade deve reduzir as desvantagens das pessoas com deficiência por meio de políticas sociais que promovam a igualdade de participação.

\section{Percepções sobre a saúde}

No final da década de 90, implantou-se a ESF a fim de que os atendimentos aos usuários fossem realizados na UBS da "Porta do Mundo", minimizando a necessidade de deslocamento para Sede ou outros municípios. A partir dos anos 2000, investiu-se no aumento da equipe e em melhoria da ambiência física na UBS, bem como a oferta de serviços foi ampliada.

A Atenção Básica se fundamente no princípio da resolutividade, identificando as necessidades de saúde, articulando tecnologias de cuidado nas intervenções setoriais e intersetoriais ${ }^{1: 3}$. Mesmo assim, os trabalhadores da ESF na "Porta do Mundo" assumem que têm dificuldades em lidar situações relacionadas às pessoas com deficiência. O desenvolvimento de ações intersetoriais é um desafio, ainda que os trabalhadores reconheçam a importância da participação de outros setores. Os entrevistados avaliam como exitosa a intervenção do Núcleo de Apoio à Saúde da Família (NASF), a qual foi interrompida devido a dificuldades no transporte da sede à UBS, fazendo com que os trabalhadores da ESF reivindicassem a ampliação da equipe.

\subsection{Modo de fazer saúde}

$\mathrm{Na}$ "Porta do Mundo", os principais focos de atenção estão no âmbito da saúde da criança e da mulher e no atendimento às condições crônicas - hipertensão arterial, diabetes, tuberculose, hanseníase e saúde mental. A deficiência, portanto, não é prioridade dentre as ações desenvolvidas pelos trabalhadores. Historicamente a saúde da pessoa com deficiência foi negligenciada pelo poder público, deixando à sociedade civil tal responsabilidade. 
Corroborando com as diretrizes da $\mathrm{RCPCD}^{1}$, os trabalhadores da ESF desenvolvem ações para identificação precoce das deficiências ao acompanhar o crescimento e desenvolvimento infantil - "Eu pego uma criança de seis meses e ela não senta. Aí eu tenho que observar uma criança de seis meses que não senta, se ela tem algum tipo de deficiência" (Entrevistado 6).

Os trabalhadores da "Porta do Mundo" desenvolvem há mais de 10 anos atividades para garantir o cuidado integral das pessoas com deficiência, ofertando assistência com equipe multidisciplinar e articulando os serviços de saúde para atender as necessidades dos usuários nas condições e tempo adequado. Essa prática corrobora com os princípios da PNAB, RCPCD e PNSIPCFA ${ }^{1: 3}$ conforme 0 relato:

[...] A menininha nasceu com síndrome de down, quando ela chegou do hospital, eu fui visitar [...] quando eu cheguei lá na casa dela, eu olhei, e observei, ela estava mamando tão devagarinho, assim, eu olhei as características dela, o choro dela, um choro bem fraquinho sabe, ai eu voltei, orientei ela direitinho, falei com ela que ela tinha que ter cuidado para dar de mamar, que ela era pequenininha e tal. Eu falei com a médica: óh, Dra. Eu quero que você vá comigo ver/ fazer visita fulana de tal porque eu fui ver a nenenzinha dela. Eu acho que essa nenenzinha dela tá com problema. Aí ela foi [...] Aí na hora a médica chamou ela, conversou com ela: sua filha tem um problema, mas tem tratamento. Vou te encaminhar para um médico, vai dar tudo certo. Encaminhou ela para Grão Mogol, para o cardiologista. Foi para Belo Horizonte, fez a cirurgia e hoje ela tá com 13 anos[...] (Entrevistado 8).

Além da dimensão técnica das ações desenvolvidas pelos trabalhadores da ESF, faz-se muito presente a dimensão da caridade. Eles relatam que estão de prontidão para "ajudar" a quem necessita, estabelecendo relações de solidariedade e reciprocidade entre trabalhadores e usuários, as quais são produzidas pelo sentimento de aliança. Essas relações são discutidas neste artigo tendo como referencial o paradigma da dádiva o qual versa sobre do ciclo do dar, receber e retribuir os bens simbólicos e materiais ${ }^{21}$. Por se reconhecerem como responsáveis pelos usuários, os trabalhadores se preocupam com o outro e se ocupam em atendê-los a qualquer momento, disponibilizando-se pelo telefone particular ou pessoalmente, inclusive fora do horário de trabalho. Essa atitude acolhedora se processa na esfera da intimidade uma vez que os usuários são seus familiares, amigos ou vizinhos. 
A não correspondência, no entanto, pode destruir tais alianças, enfraquecendo suas relações e provocando desavenças entre trabalhadores e usuários. A relação de desconfiança é exemplificada pelos trabalhadores nas situações que os usuários se recusam a receber o ACS no domicílio. Assim, o ciclo da dádiva e contradádiva pode ser rompido quando há recusa em dar, em receber ou em retribuir a ajuda, podendo causar conflitos ${ }^{21}$. Nessas situações em que há troca de agressividades, os usuários demonstram sua insatisfação quando seus problemas não são resolvidos, desconfiando da conduta e responsabilizando os trabalhadores, além de queixarem com colegas ou superiores. Por outro lado, os trabalhadores se apropriam do discurso normativo administrativo e biomédico para se impor, desconsiderando os aspectos sócio-culturais dos usuários.

\subsection{Acesso à saúde}

As falas dos trabalhadores revelam as singularidades referentes à vida no povoado e na zona rural, assim como das pessoas com ou sem deficiência. Tendo como base a literatura disponível, o acesso $^{(11)}$ à saúde pode ser discutido em duas dimensões de acessibilidade: a geográfica e a sócio-organizacional ${ }^{22}$. A geográfica é uma dimensão determinante para o efetivo uso dos serviços de saúde, podendo facilitar ou dificultar o acesso das pessoas. As barreiras geográficas são citadas por todos os trabalhadores na "Porta do Mundo", sendo que a literatura discute sobre a inadequação do transporte e a longa distância a ser percorrida na zona rural ${ }^{10}$.

O fator ambiental facilitador do acesso ao povoado é a proximidade entre o domicílio e a UBS, fazendo com que as pessoas sem deficiência e os trabalhadores desloquem-se nesse trajeto, na maioria das vezes, caminhando. Apesar da proximidade, de regra as pessoas com deficiência necessitam de transporte sanitário ou particular. Ressalta-se que no povoado é mais fácil conseguir transporte sanitário devido à organização do sistema logístico, não havendo, no entanto, transporte sanitário adaptado para pessoas com deficiência.

\footnotetext{
(11) Starfield (2002) destaca diferenças entre acesso e acessibilidade, apesar de se considerar a complementaridade desses conceitos. Para ela acessibilidade refere-se a características da oferta, sendo o acesso a forma como as pessoas percebem a acessibilidade.
} 
$\mathrm{Na}$ zona rural, os trabalhadores da ESF abordam duas barreiras geográficas: barreira física - irregularidade no solo, aclive e declive na topografia - e distância entre o domicílio e a UBS. Em geral as pessoas com ou sem deficiência e os trabalhadores não se deslocam a pé neste trajeto. As pessoas sem deficiência que vivem no campo são usualmente atendidas pelo transporte escolar que faz o percurso zona rural - povoado. Reiteram-se as limitações do transporte escolar no que se refere ao longo tempo de deslocamento. Além disso, essa estratégia resolve parcialmente o problema, porque, em alguns casos, os motoristas se recusam a realizar o transporte. Os ônibus são disponibilizados conforme o calendário escolar e as pessoas necessitam se locomover até a parada do ônibus. Observa-se, portanto, maior dificuldade de acesso ao transpor escolar, variando de acordo com a região da zona rural.

Outro aspecto da barreira geográfica na zona rural é o fato dos ACS lá lotados não comparecerem à UBS diariamente, ao contrário dos trabalhadores do povoado, comunicando-se frequentemente com a equipe por meio do telefone celular particular.

Em relação à acessibilidade sócio-organizacional, priorizou-se 0 atendimento da zona rural no turno vespertino, podendo ser atendidos de manhã em caso de urgência. Além disso, para diminuir a desigualdade de acesso entre as pessoas do povoado e da zona rural, aqueles que vivem no campo podem agendar atendimento por telefone, evitando assim que se desloquem até a UBS.

Os trabalhadores da ESF organizam o atendimento para que sejam atendidos primeiramente aqueles que vivem no campo uma vez que o transporte escolar tem horário fixo. Em alguns casos, entretanto, as pessoas retornam sem atendimento porque o médico não o atendeu. Os trabalhadores na "Porta do Mundo" não citam a prioridade de atendimento para pessoas com deficiência apesar de normativa vigente o tema ${ }^{23}$.

$\mathrm{Na}$ "Porta do Mundo", o acesso à Atenção Especializada citado pelos trabalhadores está no âmbito da saúde mental:

[...]não tinha tratamento. O povo levava era em curandeira. Gastou um dinheiro, você sabe quando ela veio melhorar? Ai ela foi fazer tratamento no 
CAPS, hoje em dia ela está outra pessoa: não surta mais. Ela não sai mais andando pro mato [...] (Entrevistado 6).

Os trabalhadores da ESF relataram que o número de vagas para consultas e exames especializados é insuficiente, resultando no longo tempo de espera. Diante disso, os usuários têm recorrido aos prestadores privados que operam valores inferiores ao atendimento particular, violando-se o direito à saúde gratuita ${ }^{24}$ e podendo gerar barreira de acesso em função da exigência de pagamento pelo usuário ${ }^{22}$.

O Plano de Ação da RCPCD em MG propõe o desenho dessa rede temática sem aprofundar no diagnóstico da capacidade instalada na Atenção Básica, bem como sem explicitar suas atribuições como coordenadora do cuidado, ignorando ainda o fato da pessoa viver na zona rural ou não ${ }^{25}$. Grão Mogol não será contemplado com Centro Especializado em Reabilitação, porque foi pactuado, na sua macrorregião de saúde, entre os Secretários de Saúde que seriam implantados cinco serviços de reabilitação os quais estão em funcionamento. Ainda assim, os trabalhadores da ESF relatam dificuldade de acesso à reabilitação das pessoas com deficiência.

\section{Considerações finais}

$\mathrm{Na}$ "Porta do Mundo", as políticas desenvolvimentistas e a inserção das políticas públicas se correlacionam diretamente com a transformação do modo de vida na zona rural. Apesar das melhorias especialmente no povoado, há necessidade de se qualificar as ações implantadas, ampliando-se efetivamente as políticas públicas para zona rural, dentre elas aquelas destinadas ao saneamento básico.

A dupla vulnerabilidade da pessoa com deficiência do campo não é abordada expressamente em documentos oficiais da RCPCD ou PNSIPCFA nem discutida na literatura nacional. Pesquisas devem ser desenvolvidas para revelar a interação entre essas duas formas de desvantagens as quais geram opressão conjuntamente, coexistindo e reforçando-se mutuamente na produção das desigualdades sociais. Essa interpretação da realidade visa subsidiar o enfrentamento e superação das barreiras de acesso à saúde das pessoas com deficiência do campo. 
O desenho da RCPCD em Minas Gerais deve ser revisto uma vez que os resultados dessa pesquisa evidenciaram as barreiras de acesso à saúde das pessoas com deficiência do campo na "Porta do Mundo". Essa repactuação do Plano de Ação deve ser conduzida de forma ascendente, do nível local para o Estadual, discutindo-se a operacionalização da rede baseada no modelo social da deficiência e na coordenação do cuidado pela Atenção Básica. O desafio é implantar políticas de saúde que garantam os princípios do SUS, considerando contextos específicos e experiências distintas na perspectiva da interseccionalidade.

\section{Referências}

${ }^{1}$ Portaria MS/GM no 793, de 24 de abril de 2012. Institui a Rede de Cuidados à Pessoa com Deficiência. Diário Oficial da União, 25 Abril 2012.

${ }^{2}$ BRASIL. Ministério da Saúde. Secretaria de Gestão Estratégica e Participativa. Departamento de Apoio à Gestão Participativa. Política Nacional de Saúde Integral das Populações do Campo e da Floresta. 1aㅡ ed. Brasília, DF: Editora do Ministério da Saúde; 2013.

${ }^{3}$ Portaria GM/MS no 2.488 de 21 de outubro de 2011. Aprova a Política Nacional de Atenção Básica, estabelecendo a revisão de diretrizes e normas para a organização da Atenção Básica, para a Estratégia Saúde da Família (ESF) e o Programa de Agentes Comunitários de Saúde (PACS). Diário Oficial da União, 24 Out 2012.

${ }^{4}$ Ayres JRCM, Calazans GJ, Saletti Filho HC, França-Júnior, I. Risco, vulnerabilidade e práticas de prevenção e promoção da saúde. In: Souza GW, Minayo MCS, Akerman M, Drumond Junior M, Carvalho, YM, organizadores. Tratado de Saúde Coletiva. Rio de Janeiro: Hucitec/Fiocruz; 2006. p. 375-417.

${ }^{5}$ Mello L, Gonçalves E. Diferença e interseccionalidade: notas para pensar práticas em saúde. Revista do programa de pós-graduação em ciências da UFRN. 2010; 2 (11); 163- 73.

${ }^{6}$ Decreto $\mathrm{n}^{\circ}$ 6.949, de 25 de agosto de 2009. Promulga a Convenção Internacional sobre os Direitos das Pessoas com Deficiência e seu Protocolo Facultativo assinados em Nova lorque, em 30 de março de 2007. Diário Oficial da União, 26 Agosto 2009. 
${ }^{7}$ Barnes C, Oliver M. Disability: A Sociological Phenomenon Ignored by Sociologists. In: Shakespeare T, organizador. The disability reader: Social science perspectives, London: Continuum; 1993. p. 65-78.

${ }^{8}$ Oliver M. Changing the social relations of research production?. Disability \& Society.1992; 2(7); 101-14.

${ }^{9}$ Lishner DM, Richardson M, Levine P, Patrick D. Access to Primary Health Care among Persons with Disabilities in Rural Areas: A Summary of the Literature. Journal of Rural Health. 1996.12 (1): 45-53.

${ }^{10}$ Iezzoni LI, Killeen MB, O'day BL. Rural residents with disabilities confront substantial barriers to obtaining primary care. Health Serv Res. 2006. 41(4): 12581275.

${ }^{11}$ Francisco V, Ravesloot C. Overview of Rural Health. Independent Living and Community Participation [Internet]. 2012 April [acesso em 15 Out 2015]; 40. Disponível em: http://scholarworks.umt.edu/ruralinst independent living community participation/40 $=$

${ }^{12}$ Bezerra ML, Bacelar T, Miranda C, Silva H. Concepções da ruralidade contemporânea: as singularidades brasileiras. 1ํㅡ ed. Brasília: IICA; 2013.

${ }^{13}$ Minayo MCS. O desafio do conhecimento: pesquisa qualitativa em saúde. 14 ${ }^{\text {a }}$ ed. São Paulo: Hucitec; 2014.

${ }^{14}$ Instituto Brasileiro de Geografia e Estatística (IBGE). Cidades. Grão Mogol. 2010 [Acesso em 18 Jul 2015]. Disponível em: http://cidades.ibge.gov.br/xtras/perfil.php?lang=\&codmun=312780\&search=minasgerais|grao-mogol.

${ }^{15}$ Campos GWS. Um método para análise e cogestão de coletivos: a constituição do sujeito, a produção de valor de uso e a democracia em instituições: 0 método da roda. $1^{\mathrm{a}}$ ed. São Paulo: HUCITEC; 2000.

${ }^{16}$ Fonseca GL. Mineração no Norte de Minas: Gerais e Geraizeiros ameaçados em função do Projeto Vale do Rio Pardo na microrregião de Grão Mogol - MG [dissertação]. Montes Claros (MG): Universidade de Montes Claros; 2014. 
${ }^{17}$ Mata Machado BN. História do Sertão Noroeste de Minas Gerais (16901930). 1aㅡ ed. Belo Horizonte: Imprensa Oficial; 1991.

${ }^{18}$ Medeiros LS, Quintans MTD, Zimmermann SA. Rural e urbano no Brasil: marcos legais e estratégias políticas. Contemporânea (Revista de Sociologia da UFSCar). 2014; 1 (4): 117-42.

${ }^{19}$ Diniz D. O que é deficiência. 1aㅡ ed. São Paulo: Editora Brasiliense; 2007.

${ }^{20}$ Shuttleworth R, Kasnitz D. The cultural context of disability. In: Albrecht GL, organizador. Encyclopedia of Disability. Thousand Oaks: Sage; 2005. p. 78-107.

${ }^{21}$ Mauss M. Ensaio sobre a Dádiva: forma e razão da troca nas sociedades arcaicas. In: Sociologia e Antropologia. São Paulo: EPU/EDUSP; 1974. p. 37-184.

${ }^{22}$ Starfield B. Atenção primária: equilíbrio entre necessidades de saúde, serviços e tecnologia. $1^{\underline{a}}$ ed. Brasília: Organização das Nações Unidas para a Educação, Ciência e a Cultura/Ministério da Saúde; 2002.

${ }^{23}$ Lei no 13.146, de 06 de Julho de 2015. Institui a Lei Brasileira de Inclusão da Pessoa com Deficiência (Estatuto da Pessoa com Deficiência). Diário Oficial da União, 07 Jul 2015.

${ }^{24}$ Lei no 8.080, de 19 de Setembro de 1990. Dispõe sobre as condições para a promoção, proteção e recuperação da saúde, a organização e o funcionamento dos serviços correspondentes e dá outras providências. Diário Oficial da União, 19 Set 1990.

${ }^{25}$ Deliberação CIB-SUS-MG n 1545, de 21 de agosto de 2013. Aprova o Plano de Ação da Rede de Cuidados à Pessoa com Deficiência do SUS-MG. Diário Oficial do Estado de Minas Gerais, 22 Agos 2013. 


\section{CONSIDERAÇÕES FINAIS}

A Atenção Básica deve ser o contato preferencial dos usuários com vistas a garantir o direito à saúde da pessoa com deficiência do campo que vivem uma condição de dupla vulnerabilidade. A inserção da interseccionalidade nas políticas de saúde pode revelar as desigualdades múltiplas, transcendendo os limites de apenas uma das vulnerabilidades. A literatura nacional e internacional sobre saúde da pessoa com deficiência do campo é escassa e a perspectiva da intersecção entre deficiência e ruralidade nas políticas de saúde tem sido pouco abordada pela literatura. Nesse contexto, foi desenvolvida a pesquisa empírica e teórica para investigar sobre a saúde das pessoas com deficiência do campo.

A partir das narrativas dos trabalhadores da UBS "Porta do Mundo", a pesquisa empírica revelou as percepções sobre saúde da pessoa com deficiência do campo. A investigação teórica derivou da empírica, aprofundando na discussão sobre deficiência e ruralidades, a partir dos princípios da Atenção Básica estruturantes nas políticas de saúde para pessoa com deficiência e para população do campo. Além disso, a pesquisa teórica explicita a intersecção entre deficiência e ruralidade nas políticas de equidade em saúde para pessoas em situação de dupla vulnerabilidade.

Esta dissertação traz as concepções de ruralidade e modelo social da deficiência, ainda que pouco utilizadas na literatura nacional e internacional. Vale ressaltar que essas concepções emergiram do debate crítico ao modelo hegemônico e fundamentaram, respectivamente, a PNSIPCFA e a RCPCD. A ressignificação do rural traz para agenda política as demandas de melhoria das condições de quem lá permanece na concepção de ruralidade. Deficiência passa a ser reconhecida como importante fenômeno sócio-politico contemporâneo no modelo social, deixando ser foco exclusivo de intervenções biomédicas. No movimento de revisar a trajetória do modo como a deficiência vem sendo historicamente tratada, a Convenção sobre os Direitos das Pessoas com Deficiência foi promulgada com equivalência de emenda constitucional no Brasil, dialogando com o modelo biomédico e social de deficiência. 
A operacionalização da investigação de campo foi desafiadora, exigindo organização logística e apoio financeiro, porque o deslocamento da mestranda se dava em duas etapas. A primeira era de Brasília no Distrito Federal para Montes Claros em MG, distando cerca de $700 \mathrm{~km}$ com tempo estimado de condução pela rodovia de quase oito horas ou voo com escala em Belo Horizonte. A segunda etapa era de Montes Claros para o Distrito de Grão Mogol, distando cerca de $160 \mathrm{~km}$ do com tempo estimado de condução pela rodovia de quase três horas. Vale destacar que alguns trechos no deslocamento rodoviário estavam em péssimo estado de conservação e havia escassas opções de transporte.

A mediação realizada pela mestranda entre a gestão local e o movimento social organizado foi imprescindível para o desenvolvimento da investigação. Os seis dias de permanência da pesquisadora no território durante a fase sistemática exigiu mais de 12 horas de trabalho diariamente a fim de cumprir os objetivos propostos nesta investigação. Fez-se necessário compreender o contexto local para proceder a coleta de dados na fase sistemática, uma vez que os trabalhadores da ESF se mostravam apreensivos e ameaçados em função das seguintes questões: envolvimento deles nos processos locais da gestão com seus grupos políticos mais defensores e críticos, trabalhadores com vínculo temporário aguardavam sua substituição por aqueles aprovados no concurso e conflitos interpessoais na equipe associados a problemas na relação entre trabalhador e usuário emergiam.

Vale ressaltar que esses desafios operacionais no desenvolvimento da pesquisa empírica foram superados com diversos apoios, dentre eles: SGEP/MS, OBTEIA/UnB, gestão local, trabalhadores da UBS e movimento social organizado. Esses elementos contribuíram para a produção de conhecimento. A investigação teórica, por outro lado, exigiu a árdua prática do exercício de pensar em uma perspectiva crítica a PNSIPCFA, a RCPCD, deficiência, ruralidade e interseccionalidade. Outro desafio nessa etapa foi a escassez de literatura.

A pesquisa empírica sobre a percepção dos trabalhadores da ESF evidenciou que as políticas desenvolvimentistas e a inserção das políticas públicas na "Porta do Mundo" se correlacionam diretamente com a transformação do modo de vida na zona rural. Apesar das melhorias especialmente no povoado, há necessidade de se qualificar as ações implantadas, ampliando-se efetivamente as políticas públicas 
para zona rural, dentre elas aquelas destinadas ao saneamento básico. $O$ desenho da RCPCD em Minas Gerais deve ser revisto uma vez que os resultados dessa pesquisa evidenciaram as barreiras de acesso à saúde das pessoas com deficiência do campo na "Porta do Mundo". Essa repactuação do Plano de Ação deve ser conduzida de forma ascendente, do nível local para o Estadual, discutindo-se a operacionalização da rede baseada no modelo social da deficiência e na coordenação do cuidado pela Atenção Básica.

Vale ressaltar que os resultados apresentados no artigo "Saúde da pessoa com deficiência do campo: o que dizem os trabalhadores da Atenção Básica?" desta dissertação são inéditos na literatura nacional por abordar a dupla vulnerabilidade das pessoas com deficiência do campo que apresentam pelo menos duas desvantagens na vida social. A intersecção entre deficiência e ruralidade é pouco abordada expressamente em documentos oficiais da RCPCD ou PNSIPCFA nem discutida na literatura nacional.

A pesquisa teórica reconhece a equidade e a integralidade do cuidado dentre os princípios estruturantes das políticas específicas de saúde para população do campo e para pessoas com deficiência. Ambos são imagem-objetivo para o fortalecimento da Atenção Básica com vistas a garantir a atenção à saúde da população do campo com deficiência. A PNSIPCFA e a RCPCD representam a conquista do espaço na agenda, valorizando o papel da Atenção Básica no contato preferencial na rede de atenção à saúde. O entrelaçamento entre essas desigualdades múltiplas, por outro lado, tem sido pouco explorado por essas políticas. A interseccionalidade pode revelar invisibilidades perpetuadoras de injustiças, contribuindo para transformar a realidade, desde que as políticas de equidade reconheçam o entrecruzamento dos eixos de subordinação que produzem desigualdades.

As políticas de equidade devem desconstruir a perspectiva universalista que não comporta o direito à diferença. Além das políticas sociais para pessoa com deficiência e para população do campo se fundamentar em princípios de justiça e inclusão social, recomenda-se que sejam repensadas no que tange a reconhecer as desigualdades múltiplas e revelar as opressões singulares, tornando visíveis as 
consequências estruturais e a interação entre os eixos de subordinação não percebidos a fim de transformar a realidade.

Pesquisas sobre intersecção da deficiência e ruralidade devem ser desenvolvidas para abordar a interação entre as formas de desvantagens que geram opressão conjuntamente, coexistindo e reforçando-se mutuamente na produção das desigualdades sociais. Essa interpretação da realidade pode subsidiar a ampliação do acesso e qualificação do atendimento às pessoas com deficiência do campo. $O$ desafio é implantar políticas de saúde que ancoradas nos princípios do SUS, considerando contextos específicos e experiências distintas na perspectiva da interseccionalidade. 


\section{REFERÊNCIAS}

ABBERLEY, P. The Concept of Oppression and the Development of a Social Theory of Disability. Disability,Handicap \& Society, Inglaterra, v. 2, n. 1, p. 5 - 19, 1987.

ALONSO, A. A introdução da interseccionalidade em Portugal: Repensar as políticas de igualdade(s). Revista Crítica de Ciências Sociais, Coimbra, v. 90, p. 2543. 2010.

AYRES,J.R.C.M.; CALAZANS,G.J.; SALETTI FILHO,H.C., FRANÇA-JÚNIOR, I. Risco, vulnerabilidade e práticas de prevenção e promoção da saúde. In: SOUZA, G.W.; MINAYO, M.C.S.; AKERMAN, M.; DRUMOND JUNIOR, M.; CARVALHO, Y.M (Org). Tratado de Saúde Coletiva. Rio de Janeiro: Hucitec/Fiocruz, 2006. p. 375-417.

BARNES, C; OLIVER, M. Disability: A Sociological Phenomenon Ignored by Sociologists, 1993. Disponível em: <http://disabilitystudies.leeds.ac.uk/files/library/Barnes-soc-phenomenon.pdf>. Acesso em: 12 abril. 2016.

BEZERRA, M.L.; BACELAR, T.; MIRANDA, C.; SILVA, H. Concepções da ruralidade contemporânea: as singularidades brasileiras. Brasília: IICA, 2013, 476p.

BRASIL. Ministério da Saúde. Secretaria de Atenção à Saúde. Departamento de Atenção Básica. Política Nacional de Atenção Básica. Brasília: Ministério da Saúde, 2012 a.110 p.

BRASIL. Ministério da Saúde. Portaria no 793, de 24 de abril de 2012. Institui a Rede de Cuidados à Pessoa com Deficiência. 2012 b. Disponível em: $<$ http://bvsms.saude.gov.br/bvs/saudelegis/gm/2012/prt0793 2404 2012.html>. Acesso em: 2 dez. 2015. 
BRASIL. Ministério da Saúde. Secretaria de Gestão Estratégica e Participativa. Departamento de Apoio à Gestão Participativa. Política Nacional de Saúde Integral das Populações do Campo e da Floresta. Brasília: Ministério da Saúde, 2013. 48 p.

BRASIL, Ministério da Saúde, Sala de Apoio à Gestão Estratégica - SAGE. 2015a. Disponível em: < http://189.28.128.178/sage/\#>. Acesso em: 18 de julho de 2015.

BRASIL, Ministério da Saúde, DATASUS, Informações de Saúde (TABNET). 2015b. Disponível em: < http://www2.datasus.gov.br/DATASUS/index.php?area=02 > Acesso em: 18 de julho de 2015.

BRASIL. Presidência da República. Decreto ํㅜ 6.949, de 25 de agosto de 2009. Promulga a Convenção Internacional sobre os Direitos das Pessoas com Deficiência e seu Protocolo Facultativo assinados em Nova lorque, em 30 de março de 2007. Disponível em: <http://www.planalto.gov.br/ccivil 03/ ato20072010/2009/decreto/d6949.htm> .Acesso em: 2 out. 2015.

BRASIL. Presidência da República. Lei no 13.146, de 06 de Julho de 2015. Institui a Lei Brasileira de Inclusão da Pessoa com Deficiência (Estatuto da Pessoa com Deficiência). Disponível em: <http://www.planalto.gov.br/ccivil 03/ Ato20152018/2015/Lei/L13146.htm>. Acesso em: 2 out. 2015.

BRASIL. Presidência da República. Lei no 8.080, de 19 de Setembro de 1990. Dispõe sobre as condições para a promoção, proteção e recuperação da saúde, a organização e o funcionamento dos serviços correspondentes e dá outras providências. Disponível em: <http://www.planalto.gov.br/ccivil 03/leis/L8080.htm >. Acesso em: 2 out. 2015.

CAMPOS, G.W.S. Um método para análise e cogestão de coletivos: a constituição do sujeito, a produção de valor de uso e a democracia em instituições: o método da roda. São Paulo: Hucitec, 2000. 236p. 
CAMPOS, G. W. S. Reflexões temáticas sobre equidade e saúde: o caso do SUS. Saude soc., São Paulo, v. 15, n. 2, p. 23-33, 2006.

CAMPOS, M.F.; SOUZA, L.A.P.; MENDES, V.L.F. A rede de cuidados do Sistema Único de Saúde à saúde das pessoas com deficiência. Interface: Botucatu, Botucatu, v. 19, n. 52, p. 207-10, 2015.

CARNEIRO, F. F. A saúde no campo: das políticas oficiais à experiência do MST e de famílias de "bóias frias" em Unaí, Minas Gerais. 2005. 143 p. Tese (Doutorado em Ciência Animal) - Escola de Veterinária, Universidade Federal de Minas Gerais, Belo Horizonte, 2007.

CECÍLIO, L.C.O. As necessidades de saúde como conceito estruturante na luta pela integralidade e equidade na atenção em saúde. In: PINHEIRO, R; MATTOS R. (Org.) Os sentidos da integralidade na atenção e no cuidado à saúde. Rio de Janeiro: IMS/ UERJ, Abrasco, 2001. p. 113-26.

DEMO, P. Metodologia do conhecimento científico. São Paulo: Atlas, 2000. $216 p$.

DINIZ, D. O que é deficiência. São Paulo: Editora Brasiliense, 2007. 96 p.

FRANCISCO, V.; RAVESLOOT, C. Overview of Rural Health. Independent Living and Community Participation, 2012. 40. Disponível em: http://scholarworks.umt.edu/ruralinst independent living community participation/40 . Acesso em: 15 out. 2015.

FONSECA, G. L. Mineração no Norte de Minas: Gerais e Geraizeiros ameaçados em função do Projeto Vale do Rio Pardo na microrregião de Grão Mogol - MG. 2014. Dissertação (Mestrado em Desenvolvimento Social) - Universidade de Montes Claros, Montes Claros, 2014. 
IEZZONI, L.I.; KILLEEN, M.B.; O'DAY, B.L. Rural residents with disabilities confront substantial barriers to obtaining primary care. Health Serv. Res., Chicago, n. 4, v. 4, p. 1258-75, 2006.

\section{INSTITUTO BRASILEIRO DE GEOGRAFIA E ESTATÍSTICA (IBGE). Cidades. Grão $2010 . \quad$ Dogol. $20 m$ : $<$ http://cidades.ibge.gov.br/xtras/perfil.php?lang=\&codmun=312780\&search=minas- gerais|grao-mogol>. Acesso em: 18 jul. 2015.}

LISHNER, D.M.; RICHARDSON, M.; LEVINE, P.;PATRICK D. Access to Primary Health Care among Persons with Disabilities in Rural Areas: A Summary of the Literature. J.rural health, Stabesboro, n. 12, v. 1, p. 45-53, 1996.

MATA MACHADO, B. N. História do Sertão Noroeste de Minas Gerais (16901930). Belo Horizonte: Imprensa Oficial, 1991. 189p.

MATTOS, R. A. Os sentidos da integralidade: algumas reflexões acerca de valores que merecem ser defendidos. In: PINHEIRO, R.; MATTOS R. (Org.) Os sentidos da integralidade na atenção e no cuidado à saúde. Rio de Janeiro: IMS/ UERJ, Abrasco, 2001. p. 39-64.

MAUSS, M. Ensaio sobre a Dádiva: forma e razão da troca nas sociedades arcaicas. In: Sociologia e Antropologia. São Paulo: EPU/EDUSP, 1974. p. 37-184.

MINAS GERAIS. Deliberação CIB-SUS-MG n 1545, de 21 de agosto de 2013. Aprova o Plano de Ação da Rede de Cuidados à Pessoa com Deficiência do SUS-MG. Disponível em:

<http://saude.mg.gov.br/images/documentos/Del\%201545\%20\%20Plano\%20de\%20a\%C3\%A7\%C3\%A3o.pdf>. Acesso em: 18 jul. 2015.

MEDEIROS, L.S.; QUINTANS, M. T. D.; ZIMMERMANN, S. A. Rural e urbano no Brasil: marcos legais e estratégias políticas. Contemporânea - Revista de Sociologia da UFSCar, São Carlos, v. 4, n. 1, p. 117-42, 2014. 
MELLO, L; GONÇALVES. E. Diferença e interseccionalidade: notas para pensar práticas em saúde. Revista do programa de pós-graduação em ciências da UFRN, Natal, v. 11, n.2, p. $163-73,2010$.

MENDES, E.V. As redes de atenção à saúde. Brasília: Organização PanAmericana da Saúde, 2011.549 p.

MINAYO, M.C.S. O desafio do conhecimento: pesquisa qualitativa em saúde. São Paulo: Hucitec, 2014. 408p.

OLIVER, M. Changing the social relations of research production? Disability \& Society, Inglaterra, v. 2, n. 7, p.101-14, 1992.

OMS. Relatório mundial sobre a deficiência. São Paulo: SEDPcD, 2012. 334 p.

Programa das Nações Unidas para o Desenvolvimento (PNUD). Atlas de Desenvolvimento Humano do Brasil 2013. Grão Mogol. Disponível em: < http://www.atlasbrasil.org.br/2013/>. Acesso em 18 de julho de 2015.

SANTOS, B. S. A crítica da razão indolente: contra o desperdício da experiência. São Paulo: Cortez, 2009. 350 p.

STARFIELD, B. Atenção primária: equilíbrio entre necessidades de saúde, serviços e tecnologia. Brasília: UNESCO/Ministério da Saúde, 2002.726p.

SHUTTLEWORTH, R.; KASNITZ, D. The cultural context of disability. In: ALBRECHT, G. L. (Org.) Encyclopedia of Disability. Thousand Oaks: Sage, 2005. p. 78-107.

WHITEHEAD, M. The concepts and principles of equity in health. International Journal of Health Services, Westport, v. 22, p. 429-445, 1992. 


\section{APÊNDICE}

APÊNDICE A - ROTEIRO DE OBSERVAÇÃO

\section{Descrições da Unidade Básica de Saúde e do Distrito Vale das Cancelas}

- Rotina e organização.

\section{Descrições dos profissionais da Estratégia de Saúde da Família}

- Comportamento e expressão do trabalhador da equipe de saúde da família ao atender as pessoas (facilidades, dificuldades e interesses) e durante a entrevista.

- Tipo de interação que se estabelece entre a população atendida e os profissionais no atendimento às pessoas.

- Compreensões de vida verbalizadas ou não (gestos e atitudes) no atendimento às pessoas.

- Acontecimentos específicos: interrupções e motivos, desdobramentos, etc.

\section{Reflexões e impressões do pesquisador}

- Impressões do pesquisador acerca do trabalhador da equipe de saúde da família, sentimentos experimentados durante o trabalho.

- Hipóteses, inferências, especulações e palpites que emergem.

- Dificuldades e dúvidas encontradas pelo pesquisador. 


\section{APÊNDICE B - ROTEIRO DE ENTREVISTA}

\section{Data:}

Horário:

\section{A. Identificação pessoal}

Fale sobre você: sua idade, estado civil, cargo que ocupa na unidade de saúde, tipo de vínculo nesta função, tempo de ocupação nesta mesma função, formação acadêmica/escolar e complementar, naturalidade, local de moradia antes de trabalhar na unidade de saúde e local de moradia atual.

B. Comunidade

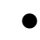

Cancelas?

\section{Cancelas?}

Cancelas?

$\bullet$

seu horário de trabalha?

C.

Relação do profissional com outras comunidades

Apresente-me o Vale das Cancelas.

Você frequenta outros distritos e cidades

fora do seu horário de trabalho?

\section{Deficiência/ Rural/ Pessoa com Deficiência do campo}

- Conte-me sobre o seu trabalho e sua rotina.

- Conte-me sobre a comunidade/os moradores do Vale das Cancelas. 
- Como você identifica as pessoas do povoado e aquelas que vivem da zona rural?

- Você atendeu ou visitou alguma pessoa com deficiência?

identifica as pessoas com deficiência?

Como você 


\section{APÊNDICE C - ROTEIRO DA RODA}

- O que é "saúde"?

- Quais são as ações de saúde oferecidas para as pessoas do Vale das Cancelas?

- Quem são as "pessoas com deficiência"?

- O que é "ser da roça"?

- Quais foram os avanços na saúde no Vale das Cancelas?

- Quais são os desafios da saúde no Vale das Cancelas? 


\section{APÊNDICE D - TERMO DE ANUÊNCIA}

Pelo presente Termo de Anuência declaro para os devidos fins de pesquisa, junto ao Comitê de Ética e Pesquisa da Faculdade de Ciências da Saúde da UnB, que a Secretaria Municipal de Saúde está ciente e de pleno acordo na realização do projeto de pesquisa intitulado PESQUISA AVALIATIVA DA IMPLANTAÇÃO DA POLÍTICA NACIONAL DE SAÚDE INTEGRAL PARA AS POPULAÇÕES DO CAMPO DA FLORESTA E DAS ÁGUAS (PNSIPCFA) EM DISTINTOS CENÁRIOS DO BRASIL.

Declaramos que apoiamos a realização do projeto nas unidades de saúde do município, conforme a metodologia preconizada pelo projeto.

Também estamos cientes que o projeto será financiado pelo Ministério da Saúde.

Secretário Municipal de Saúde

de de 


\section{APÊNDICE E - TERMO DE CONSENTIMENTO LIVRE E ESCLARECIDO}
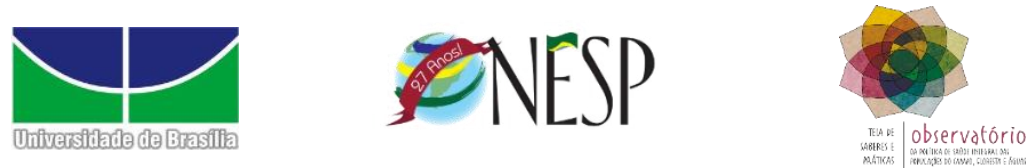

O(a) senhor(a) está sendo convidado(a) a participar do projeto de pesquisa: PESQUISA AVALIATIVA DA IMPLANTAÇÃO DA POLÍTICA NACIONAL DE SAÚDE INTEGRAL PARA AS POPULAÇÕES DO CAMPO DA FLORESTA E DAS ÁGUAS (PNSIPCFA) EM DISTINTOS CENÁRIOS DO BRASIL

Com esta pesquisa pretendemos avaliar a implementação da POLÍTICA NACIONAL DE SAÚDE INTEGRAL PARA AS POPULAÇÕES DO CAMPO DA FLORESTA E DAS ÁGUAS em distintos territórios no Brasil, como também Identificar e construir novos indicadores (qualitativos e quantitativos) e mapas com temas relacionados à implementação da PNSIPCFA.

Assim, gostaríamos de contar com a sua participação, permitindo que nos forneça informações acerca das necessidades de saúde da sua região através da sua participação em um grupo de pesquisa-ação, se necessário, uma entrevista não-diretiva gravada, lembrando que essas informações serão mantidas no anonimato, ou seja, não utilizaremos nenhum dado que possa levar a sua identificação.

Informamos que a pesquisa, aparentemente, não traz risco a sua saúde e que o(a) senhor(a) pode desistir de participar da mesma no momento em que decidir, sem que isso the acarrete qualquer penalidade. Caso ocorra algum risco, este será visto, avaliado e dado as devidas providências pela equipe de pesquisadores que constituem este projeto.

Se necessário, pode entrar em contato com o coordenador da pesquisa Prof. Dr. Fernando Ferreira Carneiro, na Faculdade de Ciências da Saúde, Departamento de Saúde Coletiva, da Universidade de Brasília (UnB), no endereço: Campus Universitário Darcy Ribeiro, s/n - Asa Norte, Brasília-DF CEP: 70910-900, fone: (61) 3107 1952, sítio: http://www.unb.br/fs .

Este projeto foi Aprovado pelo Comitê de Ética em Pesquisa da Faculdade de Ciências da Saúde, Campus Darcy Ribeiro da Universidade de Brasília, no endereço: Campus Universitário Darcy Ribeiro, s/n - Asa Norte, Brasília-DF, CEP: 70904-970.

As dúvidas com relação à assinatura do TCLE ou os direitos do sujeito da pesquisa podem ser obtidos através do telefone: (61) 3107-1947 ou do e-mail cepfs@unb.br.

Este documento foi elaborado em duas vias, uma ficará com a(o) pesquisador(a) responsável e a outra com o(a) senhor(a).

Tendo sido informado(a) sobre a pesquisa PESQUISA AVALIATIVA DA IMPLANTAÇÃO DA POLÍTICA NACIONAL DE SAÚDE INTEGRAL PARA AS POPULAÇÕES DO DA FLORESTA E DAS ÁGUAS (PNSIPCFA) EM DISTINTOS CENÁRIOS DO BRASIL, concordo em participar da mesma.

Nome:

Assinatura:

Data:

Tendo sido informado (a) sobre a pesquisa PESQUISA AVALIATIVA DA IMPLANTAÇÃO DA POLÍTICA NACIONAL DE SAÚDE INTEGRAL PARA AS POPULAÇÕES DO CAMPO DA FLORESTA E DAS ÁGUAS (PNSIPCFA) EM DISTINTOS CENÁRIOS DO BRASIL, concordo em participar da mesma.

Nome: 
Assinatura:

Data:

ANEXO

\section{ANEXO A - PARECER CONSUBSTANCIADO DO CEP}

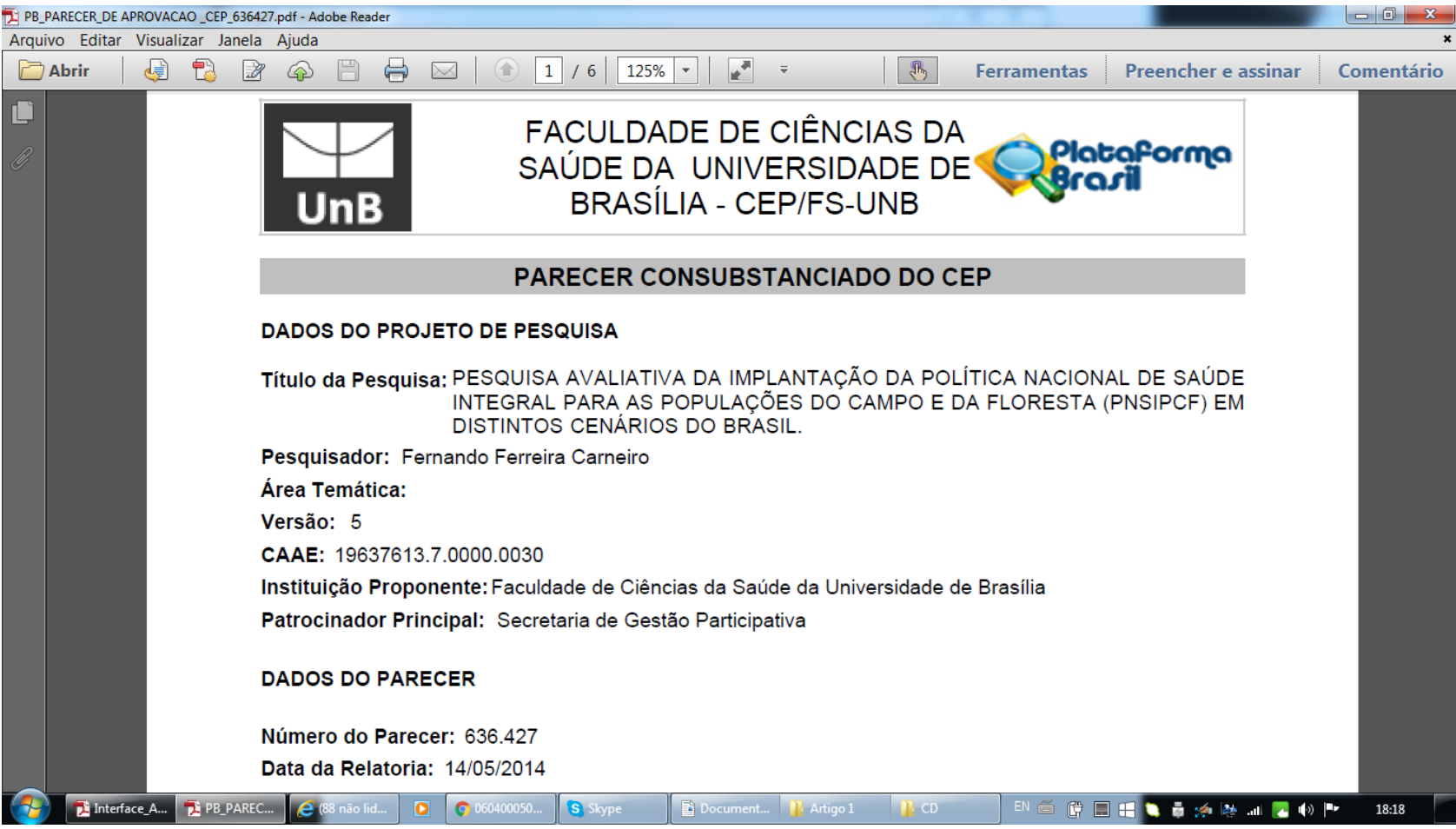

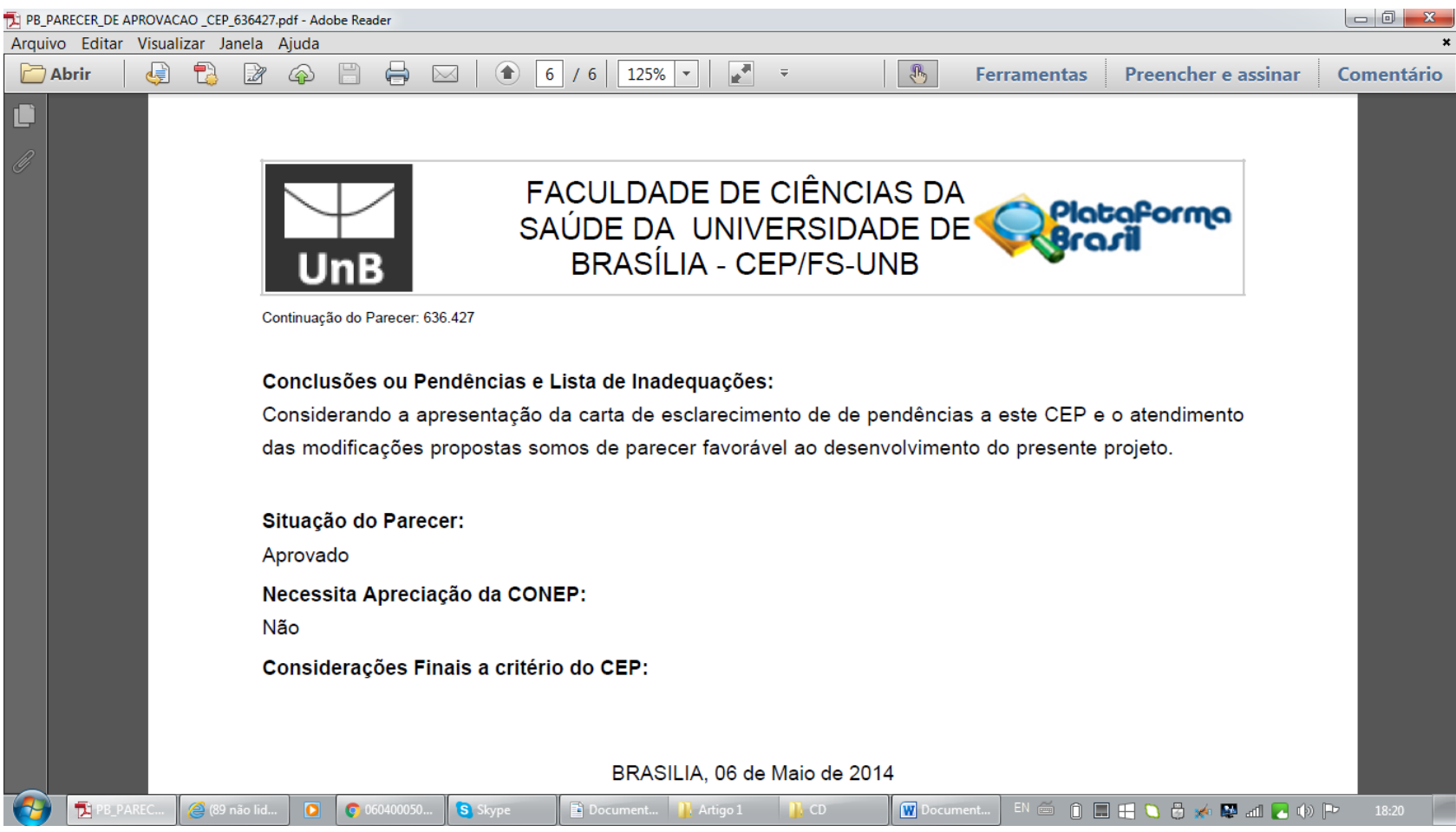




\section{ANEXO B - COMPROVANTE E SUBMISSÃO DO ARTIGO À REVISTA INTERFACE}

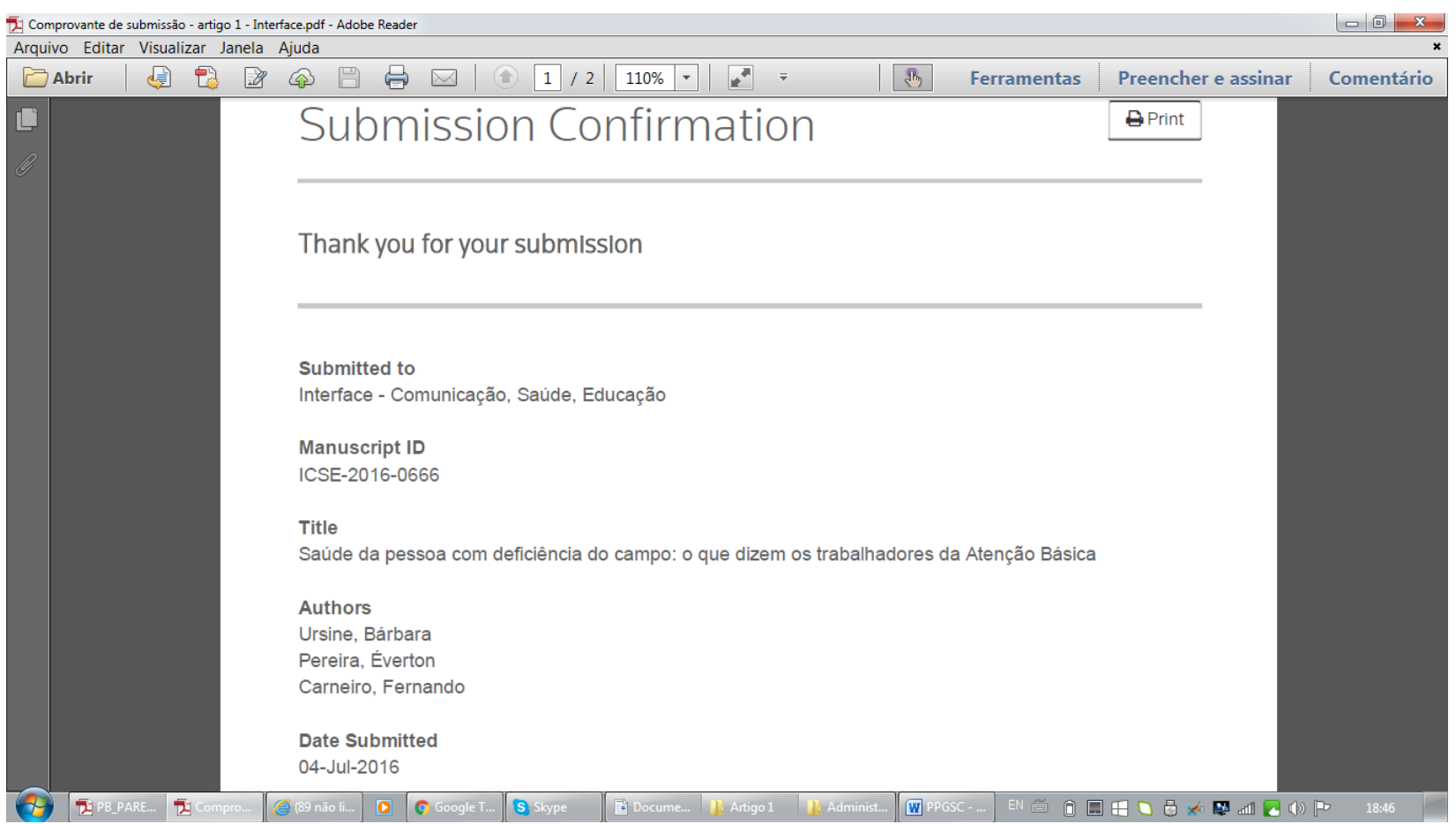

